\title{
FIELD OBSERVATIONS FROM THE JANUARY 12, 2010, HAITI EARTHQUAKE: IMPLICATIONS FOR SEISMIC HAZARDS AND FUTURE POST-EARTHQUAKE RECONNAISSANCE INVESTIGATIONS IN ALASKA
}

by

R.D. Koehler and P. Mann

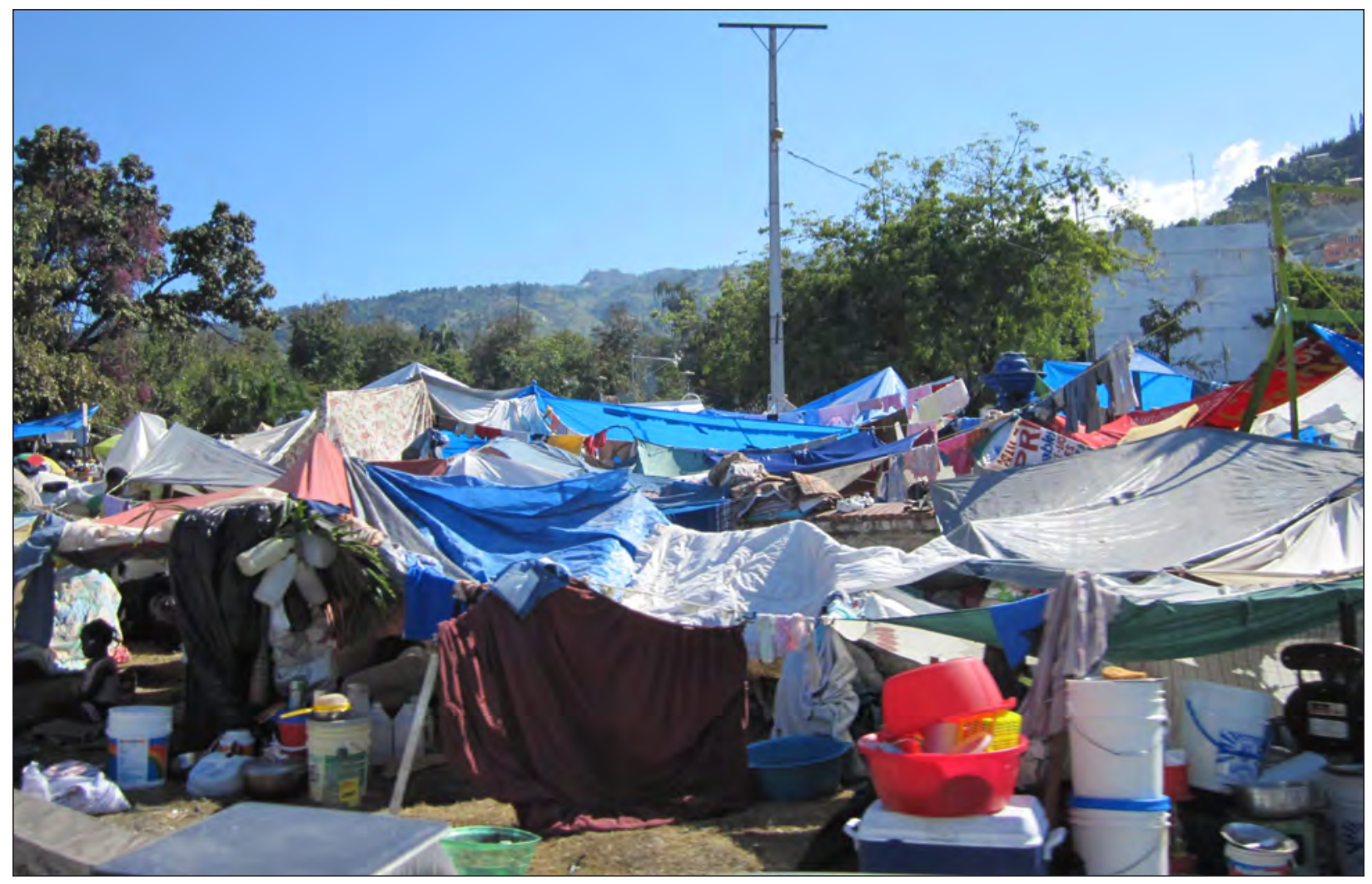

Makeshift shelters like this tent city near Pétion-Ville were created in virtually every neighborhood in Port-auPrince, Haiti, after the January 12, 2010, earthquake. More than 1 million residents were displaced by extensive damage to, and collapse of, unreinforced masonry homes.

\section{Published by}

STATE OF ALASKA

DEPARTMENT OF NATURAL RESOURCES

DIVISION OF GEOLOGICAL \& GEOPHYSICAL SURVEYS 

Report of Investigations 2011-2

FIELD OBSERVATIONS FROM THE JANUARY 12, 2010, HAITI EARTHQUAKE: IMPLICATIONS FOR SEISMIC HAZARDS AND FUTURE POST-EARTHQUAKE RECONNAISSANCE INVESTIGATIONS IN ALASKA

by

R.D. Koehler and P. Mann

2011

This DGGS Report of Investigations is a final report of scientific research. It has received technical review and may be cited as an agency publication. 


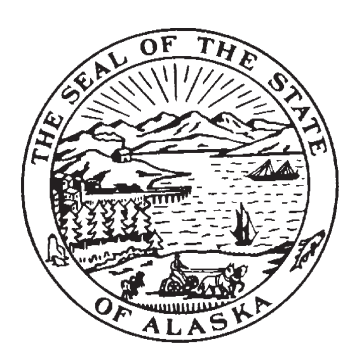

STATE OF ALASKA

Sean Parnell, Governor

DEPARTMENT OF NATURAL RESOURCES

Daniel S. Sullivan Commissioner

\section{DIVISION OF GEOLOGICAL \& GEOPHYSICAL SURVEYS Robert F. Swenson, State Geologist and Director}

Publications produced by the Division of Geological \& Geophysical Surveys can be examined at the following locations. To order publications, contact the Fairbanks office.

\section{Alaska Division of Geological \& Geophysical Surveys \\ 3354 College Rd., Fairbanks, Alaska 99709-3707 \\ Phone: (907) 451-5020 Fax (907) 451-5050 \\ dggspubs@alaska.gov \\ www.dggs.alaska.gov}

\begin{abstract}
Alaska State Library
State Office Building, 8th Floor

3354 College Road

Juneau, Alaska 99811-0571

Elmer E. Rasmuson Library

University of Alaska Fairbanks

Fairbanks, Alaska 99775-1005
\end{abstract}

\author{
Alaska Resource Library \& Information \\ Services (ARLIS) \\ 3150 C Street, Suite 100 \\ Anchorage, Alaska 99503 \\ University of Alaska Anchorage Library \\ 3211 Providence Drive \\ Anchorage, Alaska 99508
}

This publication released by the Division of Geological \& Geophysical Surveys was produced and printed in Fairbanks, Alaska, at a cost of $\$ 2.00$ per copy. Publication is authorized by Alaska Statute 41, which charges the division "to determine the potential of Alaskan land for production of metals, minerals, fuels, and geothermal resources; the location and supplies of groundwater and construction materials; the potential geologic hazards to buildings, roads, bridges, and other installations and structures; and shall conduct such other surveys and investigations as will advance knowledge of the geology of Alaska." 


\section{CONTENTS}

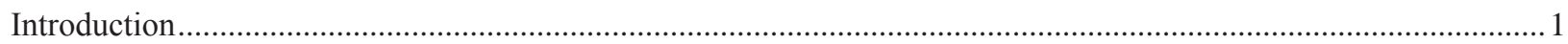

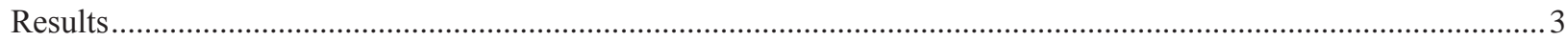

Helicopter reconnaissance along the northeastern Tiburon Peninsula ..................................................................

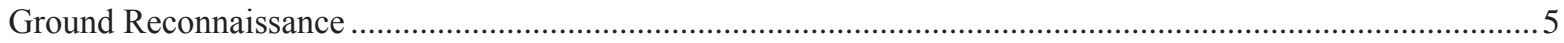

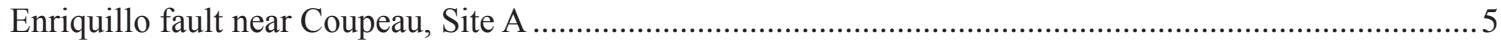

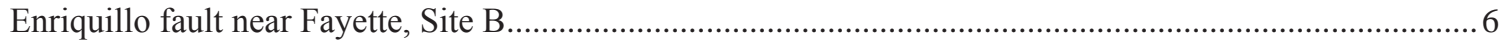

Enriquillo fault near Dufort, Site C ............................................................................................................ 12

Highway 200 between Dufort and Leogâne, Site D ..................................................................................12

Coast west of Leogâne, uplifted coral reef, Site E.......................................................................................12

River mouth directly east of Fouche, Site F......................................................................................... 19

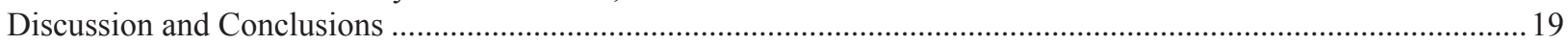

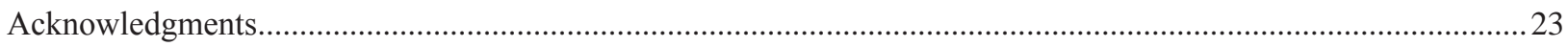

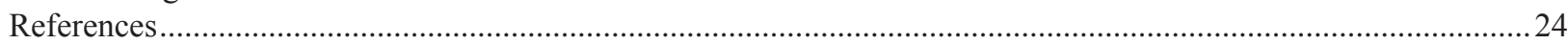

\section{TABLE}

Table 1. Summary observations from individual ground reconnaissance sites noted on figure 1 ............................ 4

\section{FIGURES}

Figure 1. Map of regional plate tectonic setting for Haiti, and terrain model map of Tiburon Peninsula and Port-au-Prince showing ground reconnaissance locations.................................................................... 1

2. Photograph showing trace of Enriquillo fault extending across deeply incised bedrock platform at

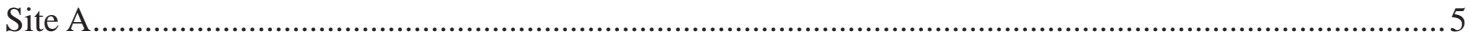

3. Photographs from Site A near Coupeau, pointing out structural features including Scarps 1 and 2 ...........6

4. Site A, showing details of specific structural features ..............................................................................

5. Pictures of Site B, east of Fayette: GoogleEarth image of Enriquillo fault where it crosses back edge of terrace east of Fayette in village of Jean-Jean; and photograph taken from helicopter showing

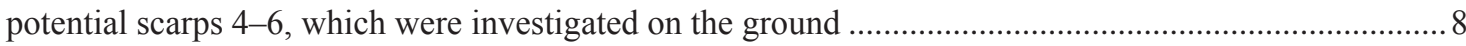

6. Potential scarps at Site B, along back edge of fluvial terrace east of Fayette............................................. 9

7. Photographs of potential scarp 6 at Site B, back edge of fluvial terrace east of Fayette ............................ 10

8. Photographs of slump feature and head scarp along range front, Site B …….......................................... 11

9. Photograph of rockfall at Site B, along back edge of terrace, and along main river channel nearby .........13

10. LiDAR image of Site $C$, fault valley southwest of Dufort .................................................................. 14

11. Photographs at Site $\mathrm{C}$, showing closed depression north $(\mathrm{CDN})$ and shutter ridge that bounds

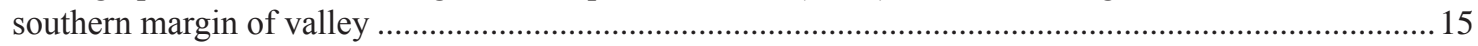

12. Photographs at Site $\mathrm{C}$, showing closed depression north $(\mathrm{CDN})$ and shutter ridge that bounds

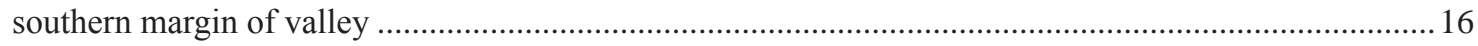

13. Site $\mathrm{C}$, showing closed depression south (CDS), dry sag pond, and cultural scarp with vegetated face

14. Site C, showing shrink-swell cracks in floor of closed depression south (CDS), displaced boulder, and toppled gravestones, all evidence of strong ground motions on south-facing slope of shutter ridge

15. Photograph of pavement cracks along Highway 200 at Site D, north of Dufort......................................... 19

16. Pictures of uplifted reef west of Leogâne (Site E), showing uplifted coral heads and exposed subtidal sea grass.

17. Photographs of uplifted reef west of Leogâne (Site E) showing drained tidal marsh, former high-tide elevation mark, and map of Haiti displaying fault near Leogâne Point .......................................21

18. Photographs of Site F, near Fouche, showing large lateral spread, and head scarp cracks on eastern side of spread 



\title{
FIELD OBSERVATIONS FROM THE JANUARY 12, 2010, HAITI EARTHQUAKE: IMPLICATIONS FOR SEISMIC HAZARDS AND FUTURE POST-EARTHQUAKE RECONNAISSANCE INVESTIGATIONS IN ALASKA
}

\author{
by \\ R.D. Koehler ${ }^{1}$ and P. Mann²
}

\begin{abstract}
The $M_{w} 7.0$ Haiti earthquake near Port-au-Prince occurred January 12, 2010, at 4:53 p.m. local time, and caused more than 230,000 fatalities. The event occurred along the Enriquillo-Plantain Garden fault zone, a major left-lateral strike-slip system that accommodates $\sim 10 \mathrm{~mm} / \mathrm{yr}$ of relative motion between the Gonave microplate and Caribbean plate. This report presents geologic observations from the epicentral region along the Enriquillo fault and illustrates how technological advances have improved post-earthquake reconnaissance. In particular, we document the lack of surface rupture along the main trace of the fault, coastal uplift of $\sim 55 \mathrm{~cm}$ at Leogâne Point, and lateral spread features up to $300 \mathrm{~m}$ wide at river delta fans near Fauche. Although the earthquake was devastating, evidence for the event will likely be poorly preserved in the geologic record and limited to subtle coastal features. This earthquake illustrates that ruptures along smaller faults adjacent to major faults can pose significant seismic hazards yet be difficult to recognize in the paleoseismic record. Documentation of the effects of this earthquake is particularly relevant for understanding these types of earthquakes and evaluating future seismic hazards along other under-studied strike-slip faults such as the Fairweather and Denali faults in Alaska.
\end{abstract}

\section{INTRODUCTION}

The 2010 Haiti earthquake occurred along the Enriquillo-Plantain Garden fault zone (EPGFZ) (fig. 1) and was one of the most lethal $\mathrm{M}_{\mathrm{w}} 7$ earthquakes in recorded history, causing widespread destruction in Port-au-Prince and the surrounding region. In the immediate aftermath of the earthquake, fears of additional temblors motivated scientific teams focused on geology, seismology, and geodesy to begin rapid assessment of the impact of the event and the potential for a future event. Although rapid reconnaissance after large-magnitude earthquakes is standard practice in the earthquake community, rapidly advancing technology in the fields of deformation monitoring, imagery, and communication have redefined the manner in which these studies are performed.

The EPGFZ is the main structural feature that cuts through the center of the southern peninsula of Haiti, and it exposes an emergent oceanic plateau complex of Late Cretaceous age. The fault is characterized by prominent tectonic geomorphology including long, linear river valleys, restraining bend push-up blocks, extensional basins along releasing bends, captured drainages, and north- and south-facing mountain escarpments. Related structural features include northwest-trending anticlines, synclines, and thrust faults (Mann and others, 1995). About 7-10 mm/yr of relative North American-Caribbean left-lateral plate motion is accommodated across the EPGFZ, with the remaining strain accommodated along the subparallel Septentrional fault system to the north (Manaker and others, 2008). Two major earthquakes that occurred about a month apart in 1751, on October 18 and November 21, affected the Azua Bay area of the Dominican Republic and the Cul-de-Sac plain areas, destroying the original settlement of Port-auPrince. Port-au-Prince was destroyed again by an event on June 3,1770, that may have been centered west of the city. Another major earthquake struck farther west on the Tiburon Peninsula on April 8, 1860. These earthquakes are assumed to have occurred along the Enriquillo fault with the exception of the first 1751 event, which may have occurred on the Muertos thrust belt. The elastic strain accumulation along the fault and the time since the last major earthquake led Manaker and others (2008) to forecast a $\mathrm{M}_{\mathrm{w}} 7.2$ event for the Enriquillo fault, comparable to the strain release in the January 12, 2010, event.

The U.S. Geological Survey's National Earthquake Information Center (NEIC) located the earthquake epicenter at $18^{\circ} 27^{\prime} 25^{\prime \prime} \mathrm{N}$ latitude and $72^{\circ} 31^{\prime} 59^{\prime \prime} \mathrm{W}$ longitude, approximately $15 \mathrm{~km}$ southwest of Port-au-Prince, close to the surface trace of the Enriquillo fault (fig. 1). Initial assessments determined that the earthquake initiated at a depth of $13 \mathrm{~km}$. The focal mechanism was consistent with oblique left-lateral strike-slip motion along a $252^{\circ}$-trending nodal plane or oblique thrusting along a northwest-trending plane. Preliminary finite fault model

\footnotetext{
${ }^{1}$ Alaska Division of Geological \& Geophysical Surveys, 3354 College Rd., Fairbanks, Alaska 99709-3707; rich.koehler@alaska.gov ${ }^{2}$ Jackson School of Geosciences, University of Texas at Austin, paulm@utig.ig.utexas.edu
} 


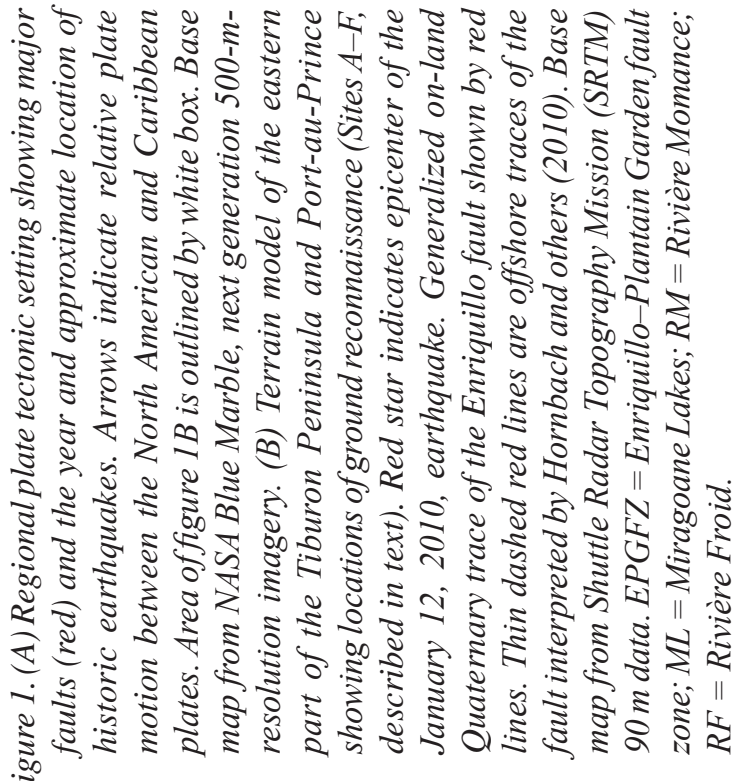
迋

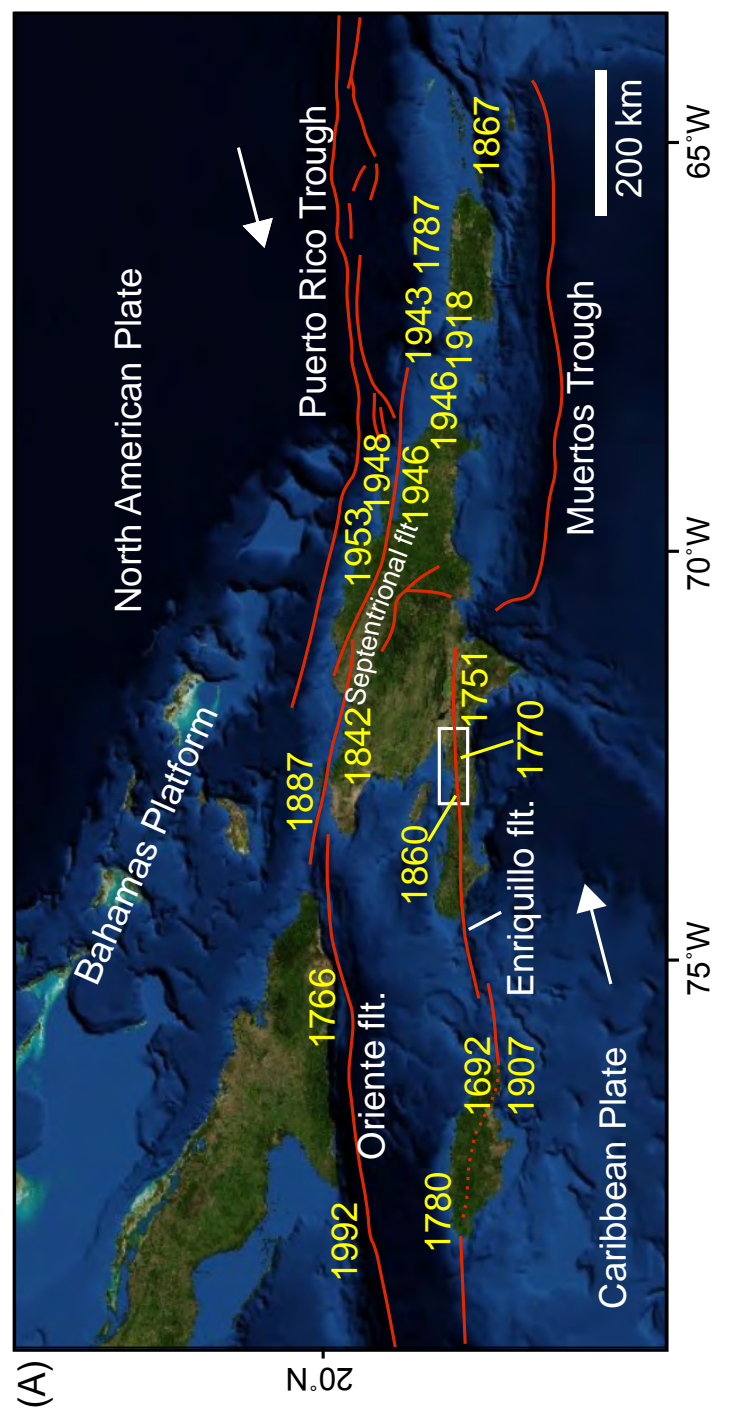

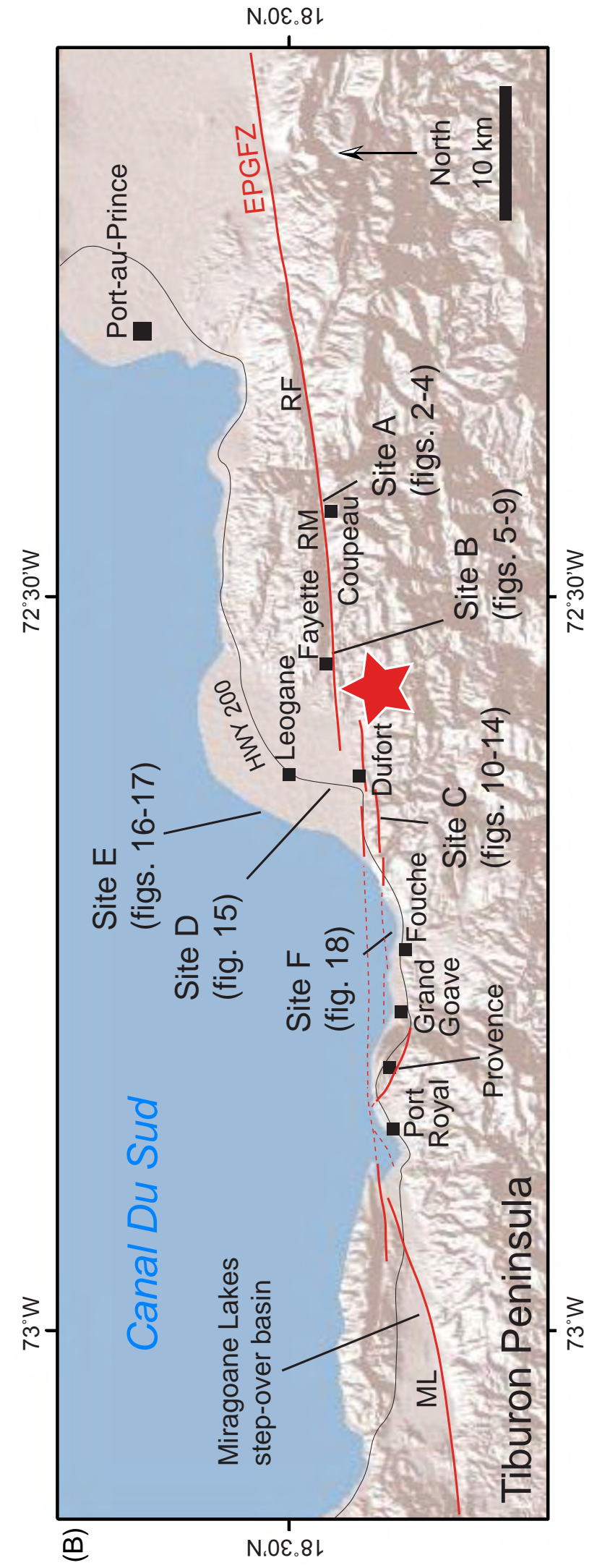


results indicate maximum slip of $\sim 4.5 \mathrm{~m}$ (mean $\sim 1.8$ $\mathrm{m}$ ) with little deformation at the surface and a seismic moment of $4.95 \times 10^{26}$ dyne-cm (NEIC, 2010). Further analysis of seismological and geodetic observations suggests that the rupture involved slip on several faults including a blind thrust fault north of the main Enriquillo fault (Hayes and others, 2010). The aftershock sequence extended predominantly west of the epicenter for $\sim 60 \mathrm{~km}$ and includes 59 earthquakes of magnitude 4.5 or greater distributed across a $\sim 30-\mathrm{km}$-wide zone. The two largest aftershocks were $M=6.0$ and $M=5.9$, which occurred seven minutes after the main shock and on January 20, 2010. The aftershocks show predominantly strike-slip motion; however, several thrust earthquakes also occurred. The western end of the aftershock sequence is in the vicinity of Port Royal at a prominent 3-5-kmwide left stepover responsible for the Miragone Lakes stepover basin.

Within days after the earthquake an unprecedented number of satellite-imagery products were made available via the internet by numerous government, academic, and industry sources. The Haiti earthquake supersite (http://supersites.unavco.org/haiti.php\#Mon3), in conjunction with the National Aeronautics and Space Administration (NASA), the European Space Agency (ESA), and the National Science Foundation (NSF), provided easy access to real-time data on SAR and GPS deformation measurements, topographic imagery, seismology, and links to other Haiti-specific websites. Websites sponsored by other agencies included those of the U.S. Geological Survey (USGS), Pacific Earthquake Engineering Research Center (PEER), and the Earthquake Engineering Research Institute (EERI). National Oceanic and Atmospheric Administration (NOAA) and GeoEye Inc. imagery shot the day after the earthquake and LiDAR (Light Detection And Ranging) data acquired by the World Bank were made available through Google Earth, providing the international earthquake community the opportunity to compare pre- and post-earthquake images and search for possible surface ruptures. The amount and availability of information facilitated a large number of independent observations from interested parties around the world.

This study represents one part of the National Science Foundation's Rapid Response investigation of the epicentral region and focuses on documenting the geologic effects of the earthquake. The primary objectives of our study were to search for, document, and map any surface faulting, refine mapping of the fault trace geometry, and document other secondary effects. We performed helicopter and ground reconnaissance surveys, based on inspection of imagery, along the well defined trace of the Enriquillo fault. We also navigated to specific features (such as rockfall and pavement cracks) based on interpretations of "near-real-time" imagery communicated via email and text messaging by the international earthquake geology community. This communication also informed us of damage and deformation along the coast including uplift and exposed reefs near Leogâne and lateral spreads along river deltas between Fouche and Grande Goâve.

The observations contained in this report provide baseline information for future studies of earthquake processes and effects. Many of the geologic features described are ephemeral and subject to removal by erosion and redevelopment activities. Accurate documentation of the geologic effects provides useful information for recognizing evidence of past earthquakes, as well as assessing future earthquake potential in Haiti and along similar strike-slip faults elsewhere. Specifically in Alaska, these data are important for assessing seismic hazards along the Fairweather, Denali, Totschunda, and other strike-slip faults.

\section{RESULTS \\ HELICOPTER RECONNAISSANCE ALONG THE NORTHEASTERN TIBURON PENINSULA}

To document the presence or absence of surface rupture as well as other features related to coseismic shaking and deformation, we performed helicopter reconnaissance along the Enriquillo fault from the area of the epicenter in the Rivière Momance fault valley to the vicinity of Port Royal and the Mirogane Lake stepover basin. The Rivière Momance fault valley is a linear, east-west-trending, steep-walled canyon. A low divide separates the Rivière Momance from the Rivière Froide to the east, and both rivers have distinct 90 -degree bends where they intersect the fault. The morphology of the fault valley is similar to other major strike-slip fault zones where low divides, elongate drainages, elevated terraces, cumulative scarps, shutter ridges, beheaded drainages, offset stream channels, and debris-slide amphitheaters occur along the fault and are indicative of active faulting. In particular, the valley is topographically similar to the Garcia/Gualala river valleys along the San Andreas fault in northern California (Prentice, 1989; Brown and Wolf, 1972; Wallace, 1990; Koehler and others, 2005), indicating a long history of strike-slip deformation. Along the fault valley, the fault primarily trends along the southern valley side slope and cuts across several incised bedrock platforms. The river meanders across the trace of the fault in places, however, the channel is not displaced. Despite the strong macro-scale tectonic geomorphology, we observed neither continuous youthful Holocene scarps nor a recent surface rupture extending between individual geomorphic features.

Landslide head scarps and debris avalanche chutes are common along the sidewalls of the Rivière Momance canyon. Evidence for coseismic landslides, rockfalls, 
and debris avalanches were observed along the entire length of the valley and include debris aprons at the bases of slopes that sometimes deflect the river, and piles of rocks and debris deposited on the river alluvium. In many cases, we noted these hill-slope features to be reactivated slides within older landslide and debris chutes on the basis of the distinct white color of the freshly exposed surface.

We also flew north of Dufort perpendicular to the fault and parallel to Highway 200 to Leogâne and along the coast from Leogâne to Port Royal. Severe cracking of the highway south of Leogâne related to roadbed settling and several coseismically uplifted coral reefs along the coast west of Leogâne were observed. Large lateral spread features and associated coast parallel cracks, head scarps, and submerged trees in growth position were observed at river delta mouths between Grande Goâve and Fouche. In the vicinity of Provence, a prominent topographic high is oriented $\mathrm{N} 55^{\circ} \mathrm{W}$ along the coast. Along the coast side of this mountain, extensive fresh debris avalanches characterized by uneroded debris cones at the base of the slope are evidence of coseismic slope processes. A linear valley with deflected drainages along the southwestern side of the mountain may indicate a fault strand and possible restraining bend in the fault. Aerial observations from the Port Royal area indicate that the fault comes onshore along the north side of the bay and projects west along the base of a $260^{\circ}$-trending linear ridge into a sidehill linear valley for several kilometers before stepping left to the vicinity of Miragone Lakes (Hornbach and others, 2010). Near Port Royal, scarps or surface cracks were not observed from the air. Subsequent to our air reconnaissance, Prentice and others (2010) observed right-stepping en echelon down-to-the-south extension fractures consistent with left-lateral slip along the on-land projection of the fault at Port Royal. The helicopter observations were used to guide our subsequent ground reconnaissance in the vicinities of Coupeau and Fayette (Sites A and B, fig. 1), Dufort (Site C, fig. 1), Highway 200 (Site D, fig. 1), the coast west of Leogâne (Site E, fig. 1), and the Fouche coast (Site F, fig. 1). The results of our ground reconnaissance at these sites are summarized in table 1.

Table 1.Summary observations from individual ground reconnaissance sites noted on figure 1 (Sites A-F).

\begin{tabular}{|c|c|c|c|}
\hline Site & Location & $\begin{array}{l}\text { Associated } \\
\text { Figures }\end{array}$ & Observations \\
\hline A & $\begin{array}{l}\text { Enriquillo fault in } \\
\text { Rivière Momance val- } \\
\text { ley near Coupeau }\end{array}$ & $2-4$ & $\begin{array}{l}\text { No surface rupture along main trace of fault; linear valleys, } \\
\text { offset streams, and beheaded channel suggest Quaternary dis- } \\
\text { placement; landslides and topple blocks; unfaulted footpath; } \\
\text { several scarps determined to be cultural in origin or possibly } \\
\text { related to prior earthquakes }\end{array}$ \\
\hline B & $\begin{array}{l}\text { Enriquillo fault in } \\
\text { Rivière Momance val- } \\
\text { ley near Fayette }\end{array}$ & $5-9$ & $\begin{array}{l}\text { No surface rupture along main trace of fault; faceted and } \\
\text { oversteepened range front suggests Quaternary displacement; } \\
\text { several scarps determined to be cultural in origin or possibly } \\
\text { related to prior earthquakes; slump block along range front } \\
\sim 15 \text { m wide; abundant rockfall }\end{array}$ \\
\hline $\mathrm{C}$ & $\begin{array}{l}\text { Enriquillo fault } \sim 1 \mathrm{~km} \\
\text { southwest of Dufort }\end{array}$ & $10-14$ & $\begin{array}{l}\text { No surface rupture within closed depressions is interpreted } \\
\text { as location of the fault; geomorphology suggests Quaterna- } \\
\text { ry activity that includes beheaded channels, linear valleys, } \\
\text { shutter ridges, closed depressions, and ponds; one scarp } \\
\text { interpreted to be of agricultural origin; boulders and grave } \\
\text { stones toppled }\end{array}$ \\
\hline $\mathrm{D}$ & $\begin{array}{l}\text { Highway } 200 \text { between } \\
\text { Leogâne and Dufort }\end{array}$ & 15 & Localized settlement and cracking of road fill prism \\
\hline $\mathrm{E}$ & Coast west of Leogâne & $16-17$ & $\begin{array}{l}\text { Uplifted coral reef; drained intertidal lagoon; exposed } \\
\text { coral heads at high tide; prominent high-tide stain line on } \\
\text { concrete wall above present high tide }\end{array}$ \\
\hline $\mathrm{F}$ & $\begin{array}{l}\text { River mouth directly } \\
\text { east of Fouche. }\end{array}$ & 18 & $\begin{array}{l}\text { Lateral spread in river mouth delta fan sediments; heads- } \\
\text { carp cracks } 2 \mathrm{~m} \text { wide and >1 m deep; liquefaction and } \\
\text { vented sand }\end{array}$ \\
\hline
\end{tabular}




\section{GROUND RECONNAISSANCE}

\section{Enriquillo fault near Coupeau, Site A}

We inspected the fault on the ground near the village of Coupeau west of the drainage divide between the Rivière Momance and Rivière Froide (Site A, fig. 1). At Site A $\left(18^{\circ} 28^{\prime} 38^{\prime \prime} \mathrm{N}, 72^{\circ} 25^{\prime} 57^{\prime \prime} \mathrm{W}\right)$, the fault extends across a deeply incised bedrock platform and is characterized by a prominent linear valley bound on the north by a large shutter ridge (fig. 2). At the western side of the linear valley a beheaded channel extends to the north (fig. 3A). Several traverses were walked perpendicular to the fault across the linear valley. We observed two scarps (Scarps 1 and 2) along the southern side of the linear valley and a scarp (Scarp 3) that extends down the middle of the valley (figs. 3B, 3C, and 4A). Scarp 1 is about $0.5 \mathrm{~m}$ high and extends along the crest of the southern linear valley wall along the eastern side of the linear valley (fig. 3B). This scarp is not continuous and extends for approximately $30 \mathrm{~m}$. Scarp 2 extends along the base of the southern valley wall of the linear valley (fig. 3C). This scarp has a similar height to Scarp 1 and is also not continuous. Scarps 1 and 2 have rounded morphology and living vegetation growing on the scarp face, indicating that they were not produced by the 2010 earthquake. We infer that these scarps are related to agricultural practices in the area, or may possibly be related to older earthquakes. Scarp 3 is about $0.5-0.75 \mathrm{~m}$ high and is characterized by a south-facing linear mound of cobbles and boulders at the base of the shutter ridge (fig. 4A). The rocks range in size from $\sim 6 \mathrm{~cm}$ to $>25 \mathrm{~cm}$ in diameter and have been colonized by grass and small brush. Freshly exposed surfaces were not observed along Scarp 3. The local farmers indicated that the rocks were excavated off the face of the shutter ridge and rolled down the hill during preparation for farming. Thus, we infer that Scarp 3 is not of tectonic origin. Figures 3A and $4 \mathrm{~B}$ show a well traveled footpath that extends across the eastern end of the linear valley roughly perpendicular to the fault trace. The path is not displaced, providing additional support for the lack of surface rupture at this location. Several slope-parallel fractures bounding perched topple blocks along the eastern side of the bedrock platform (fig. 4C), and fresh debris avalanches were also observed near Site A (fig. 4D).

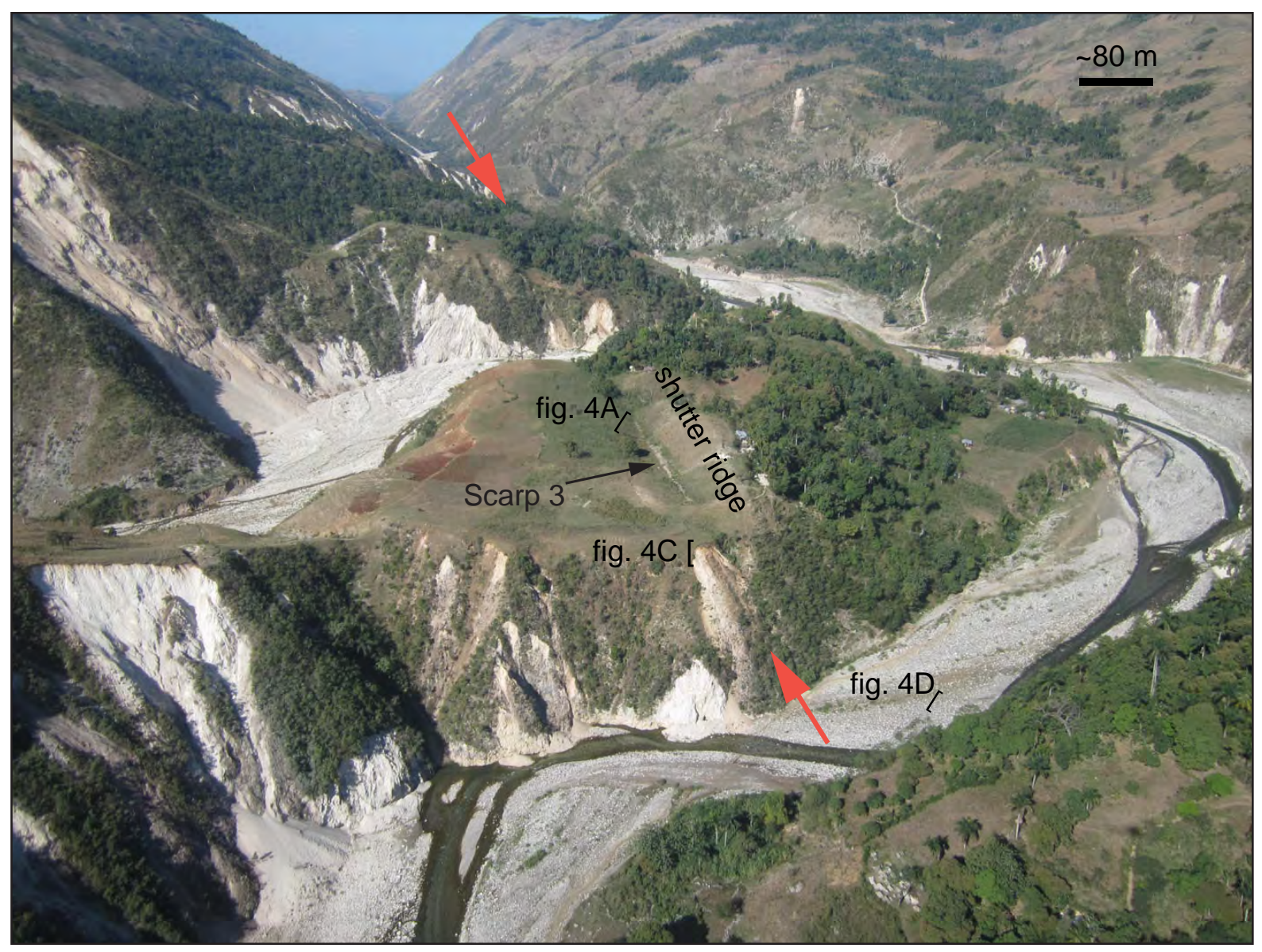

Figure 2. Photograph showing trace of Enriquillo fault extending across deeply incised bedrock platform at Site A; view is to the west. Fault extends between red arrows. Scarp 3 extends along the base of a linear valley. Brackets mark locations of photographs $A, C$, and D in figure 4. 


\section{Enriquillo fault near Fayette, Site B}

We investigated the fault on the ground at a second location, Site B $\left(18^{\circ} 28^{\prime} 20^{\prime \prime} \mathrm{N}, 72^{\circ} 32^{\prime} 24^{\prime \prime} \mathrm{W}\right)$, where it projects along the base of a faceted slope at the back edge of a fluvial terrace along the southern side of the Rivière Momance fault valley east of the town of Fayette (fig. 5). At this location, dark shadows along the base of the slope observed from the helicopter and on GeoEye, Inc. imagery indicated the possible presence of surface rupture. Figure 5B shows three potential scarps investigated in the field. Observations along these scarps indicate that primary surface rupture did not occur along these features during the 2010 earthquake. Potential scarp 4 projects away from the range front and is a 1 -m-high
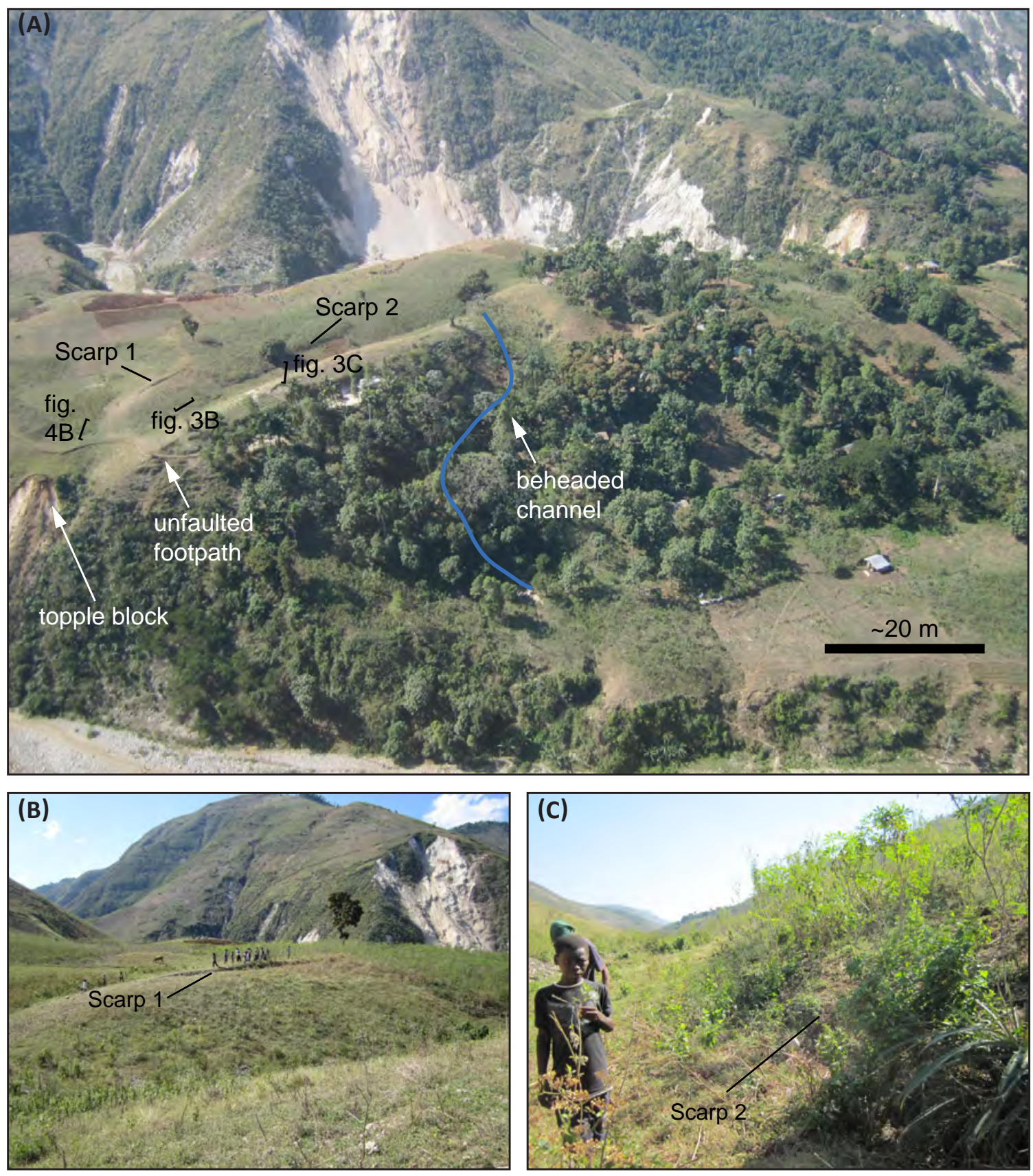

Figure 3. Photographs from Site A near Coupeau. (A) Looking southwest at linear valley of the Enriquillo fault. Scarps 1 and 2 along the southern side of the linear valley are back-shadowed. Brackets mark locations of photographs in figures 3B, 3C, and 4B. (B) View to the south across linear valley. Local villagers standing on top of Scarp 1 provide scale. (C) Photograph showing vegetated face of Scarp 2. Children provide scale. 
escarpment with a rounded crest, vegetated face, and linear mound of soil that forms a trough parallel to the base of the scarp (fig. 6A). We infer that the mound of soil was constructed by farmers to divert water from the creek east of the scarp to irrigate crops. Potential scarp 5 is about $0.5 \mathrm{~m}$ high, has a rounded crest and base, and has been colonized by grass (fig. 6B). Freshly exposed surfaces were not observed along the base of potential scarps 4 and 5. Potential scarp 6 ranges in height from about 1 to $2 \mathrm{~m}$ and projects along the base of the range front (fig. 7). Several gullies have incised through the scarp to the base of the slope and the scarp does not cut across these features (figs. 7A and 7B). The base of the scarp is commonly buried by small landslides and topple blocks of soil and vegetation sourced from the crest of the scarp (fig. 7C). Where the base of the scarp is exposed, the profile is smooth and not fractured. Soil is exposed in the face of the scarp; however, sparse grass growing on the face indicates it is not a fresh surface.
Although we cannot preclude that potential fault scarps 4-6 were originally formed by paleoearthquakes, our field observations indicate that they were not created or reactivated during the 2010 earthquake. A left-laterallyoffset channel margin ( 1 m) was observed directly east of the potential scarps and likely represents offset from a previous earthquake (fig. 5B). Similar channel offsets were observed along the range front east of our site (Prentice and others, 2010).

Secondary tectonic features observed at Site B include an earth slump and rockfall. A small earth slump occurs along the fault trace. The location of the slump is shown on figure 5 and photographs of the feature are shown on figure 8 . The slump is characterized by a 15-cm-high fresh head scarp that is about $12 \mathrm{~m}$ long (fig. 8). The head scarp is slightly arcuate and the vertical separation across it diminishes on either end where the scarp intersects the face of the slope. On the basis of the spatial coincidence of the head scarp with the trace of
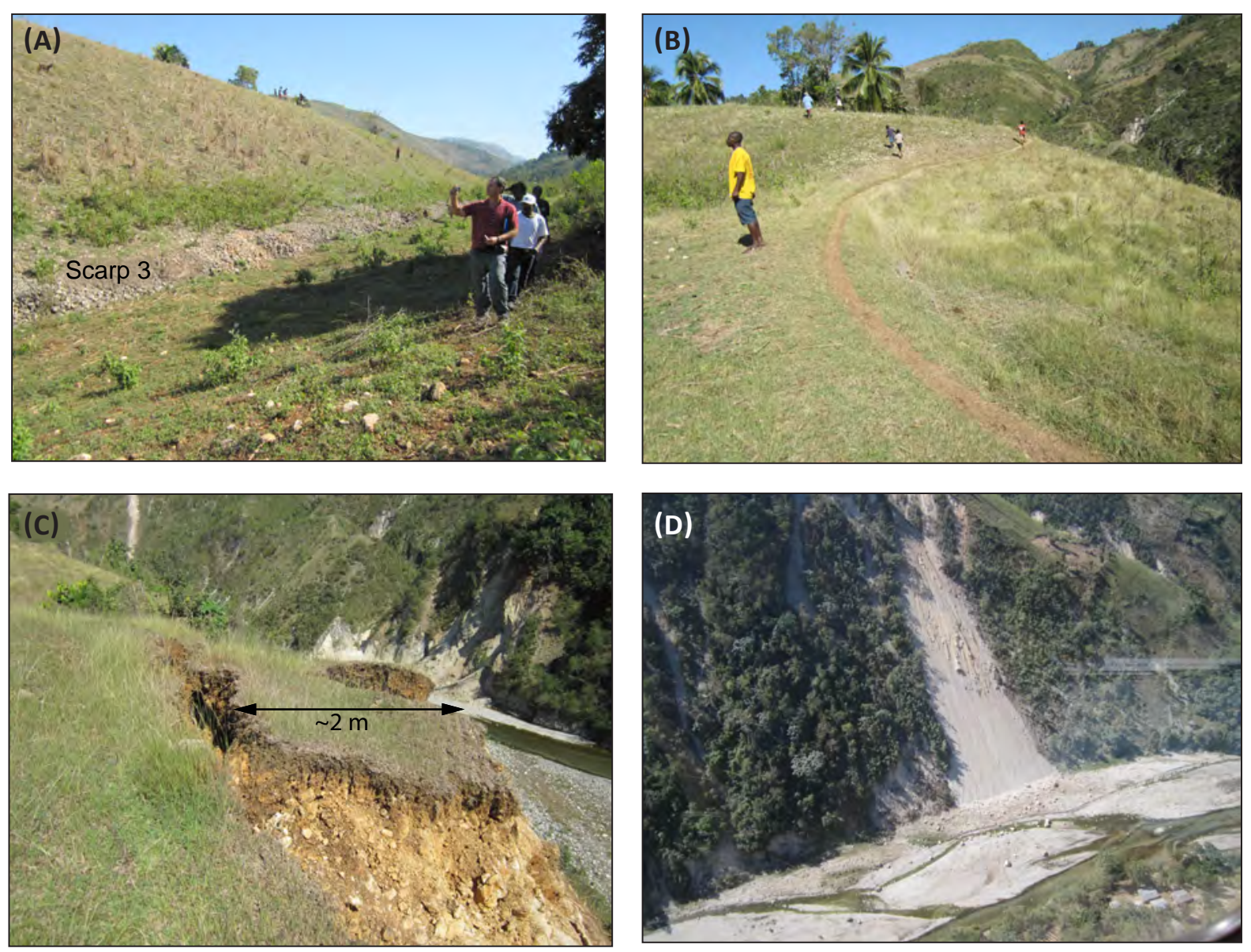

Figure 4. Additional photographs from Site A; their locations are pointed out on figures 2 and 3. (A) Linear mound of cobbles and boulders (Scarp 3) at the base of the shutter ridge; people provide scale. (B) Footpath crosses the fault and is not offset; people for scale. (C) Approximately 2-m-wide perched topple block separated from hillside by an $\sim 0.5$-m-deep fracture parallel to the slope. (D) Rockfall/debris avalanche along the southern valley wall of the main river channel. Scar of the failure is $\sim 60 \mathrm{~m}$ high. 


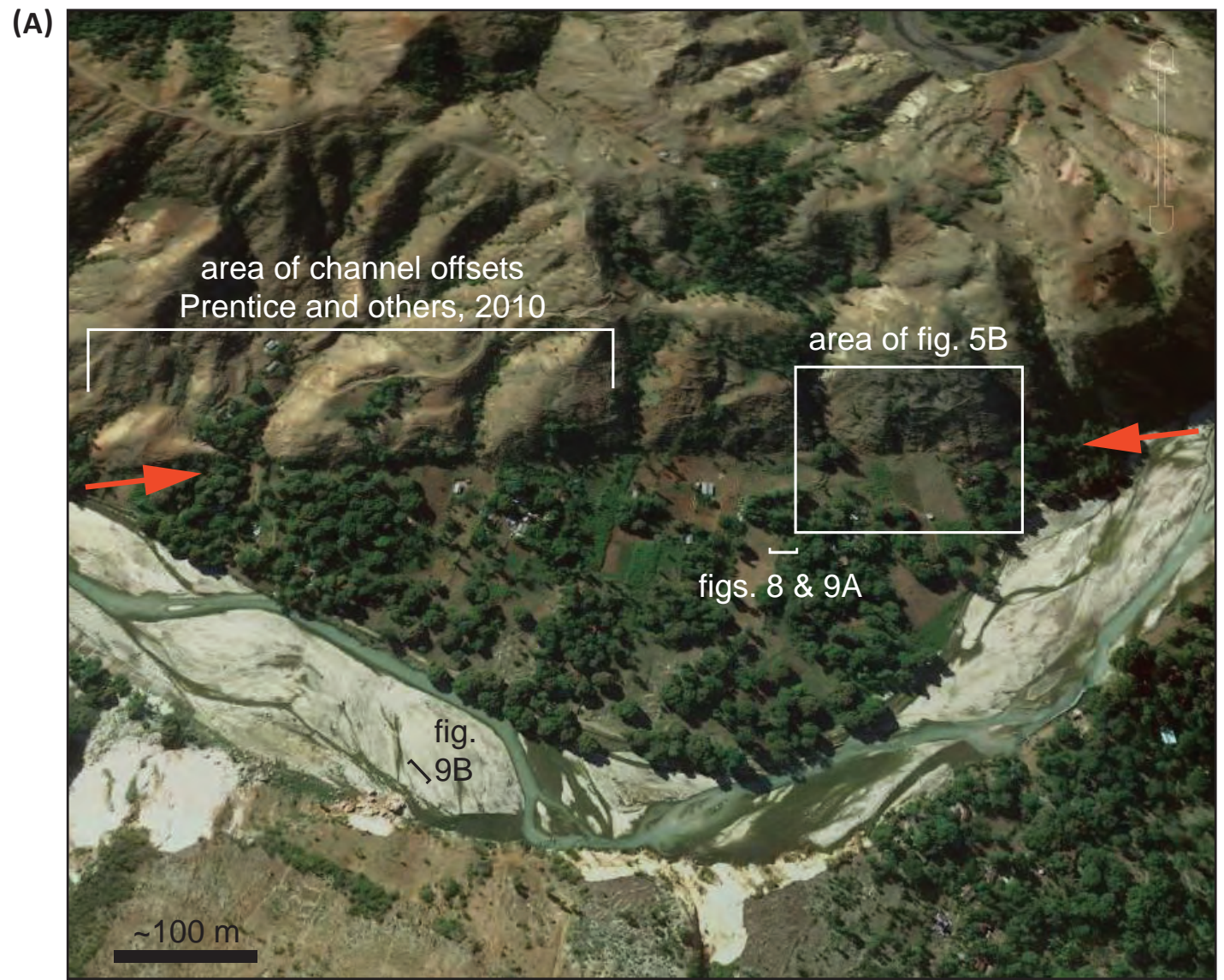

(B)

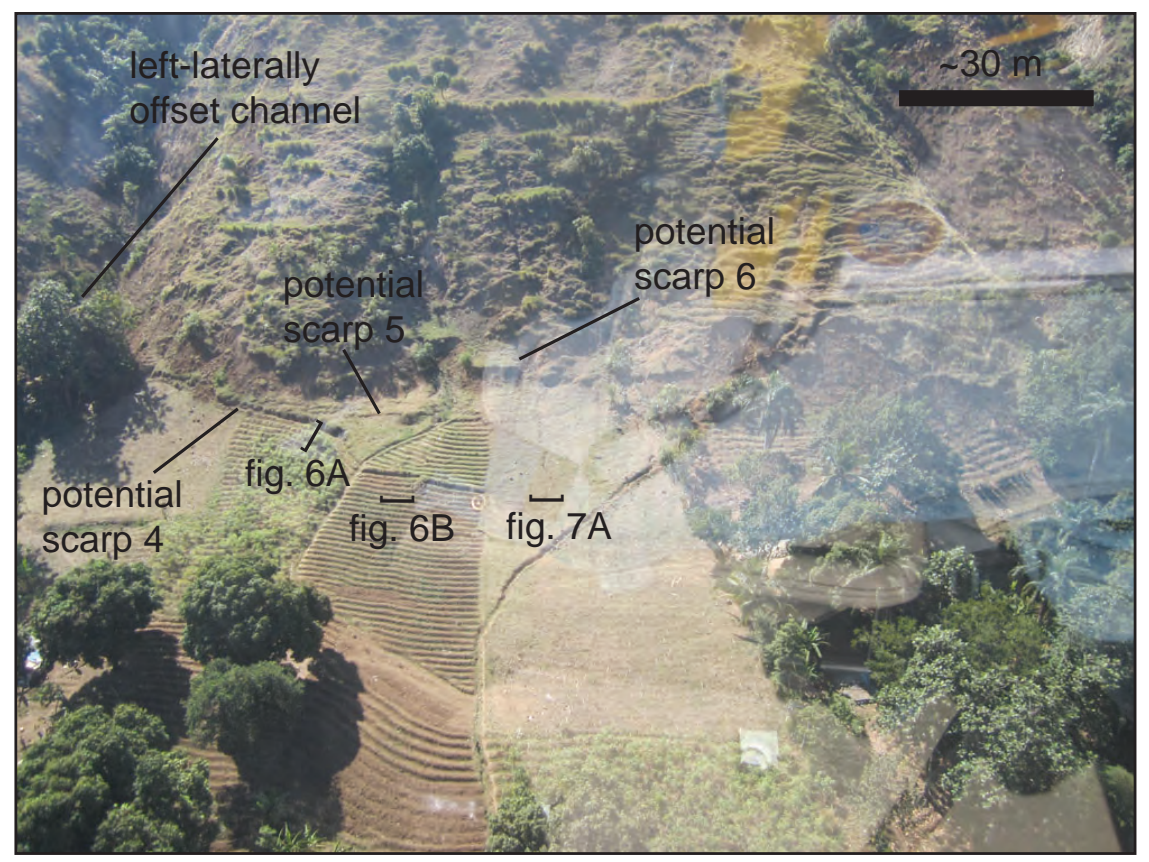

Figure 5. Photographs from Site B, east of Fayette. (A) GoogleEarth image looking south at Enriquillo fault where it crosses the back edge of a terrace east of Fayette in the village of Jean-Jean. Fault extends between red arrows. Brackets mark locations of photographs in figures 8, 9A, and 9B; white box shows location of figure 5B. (B) Enlarged photograph taken from helicopter showing potential scarps 4, 5, and 6, which were investigated on the ground. Brackets mark locations of photographs in figures $6 \mathrm{~A}, 6 \mathrm{~B}$, and $7 \mathrm{~A}$. 
(A)

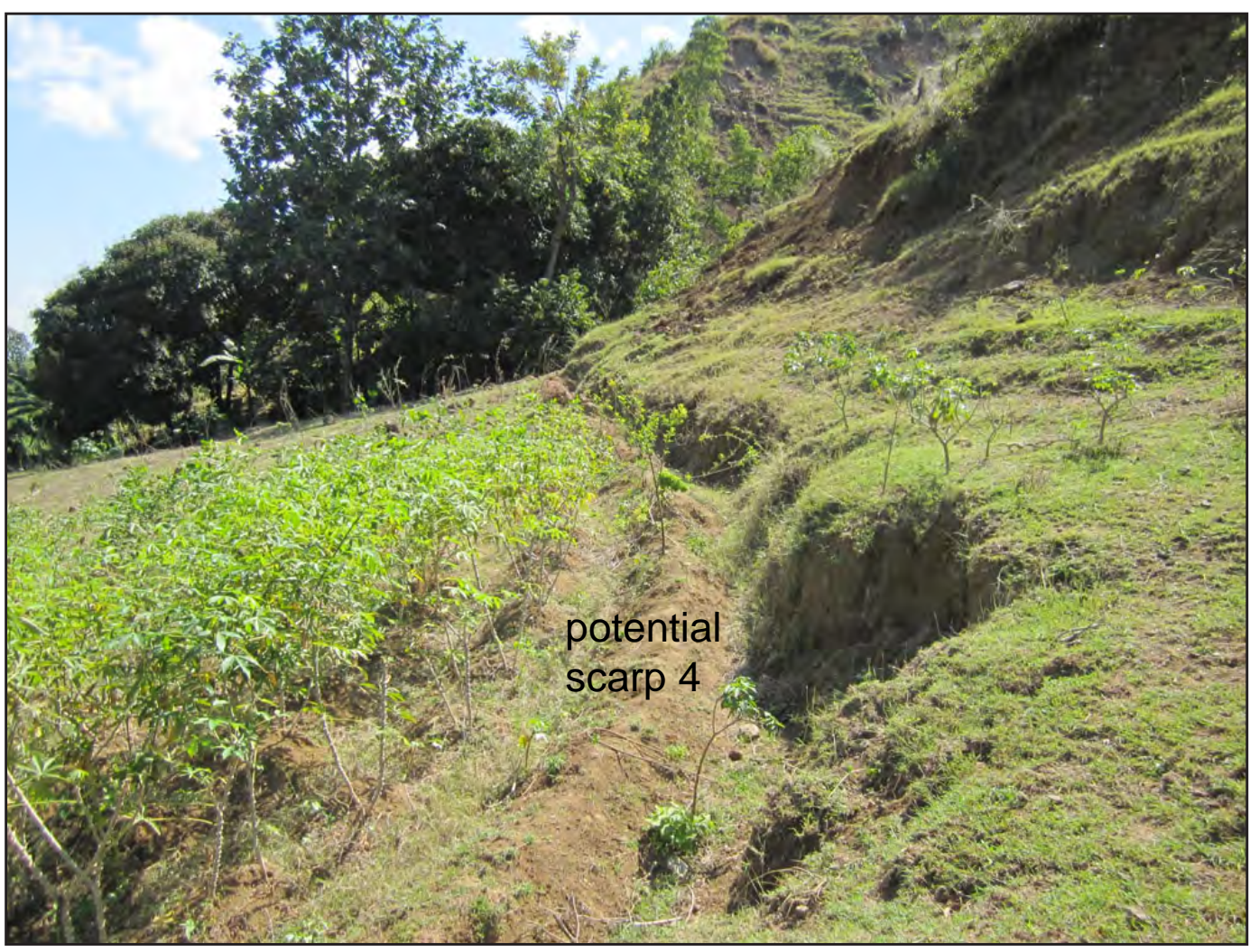

(B)

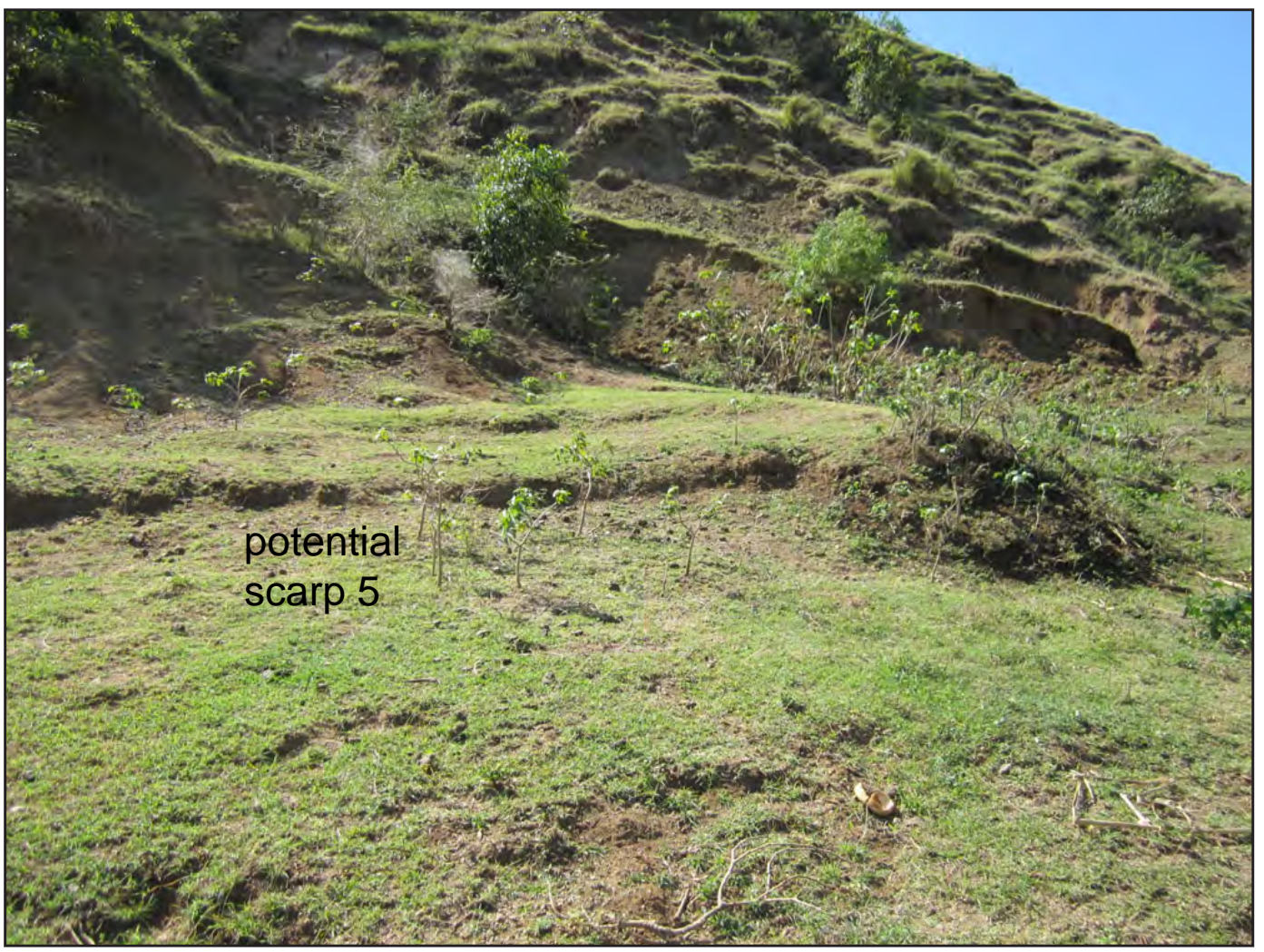

Figure 6. Photographs of potential scarps along the back edge of a fluvial terrace east of Fayette at Site B; figure 5 shows their locations. (A) Potential scarp 4, approximately $1 \mathrm{~m}$ high, and (B) potential scarp 5, approximately $0.5 \mathrm{~m}$ high. 
(A)

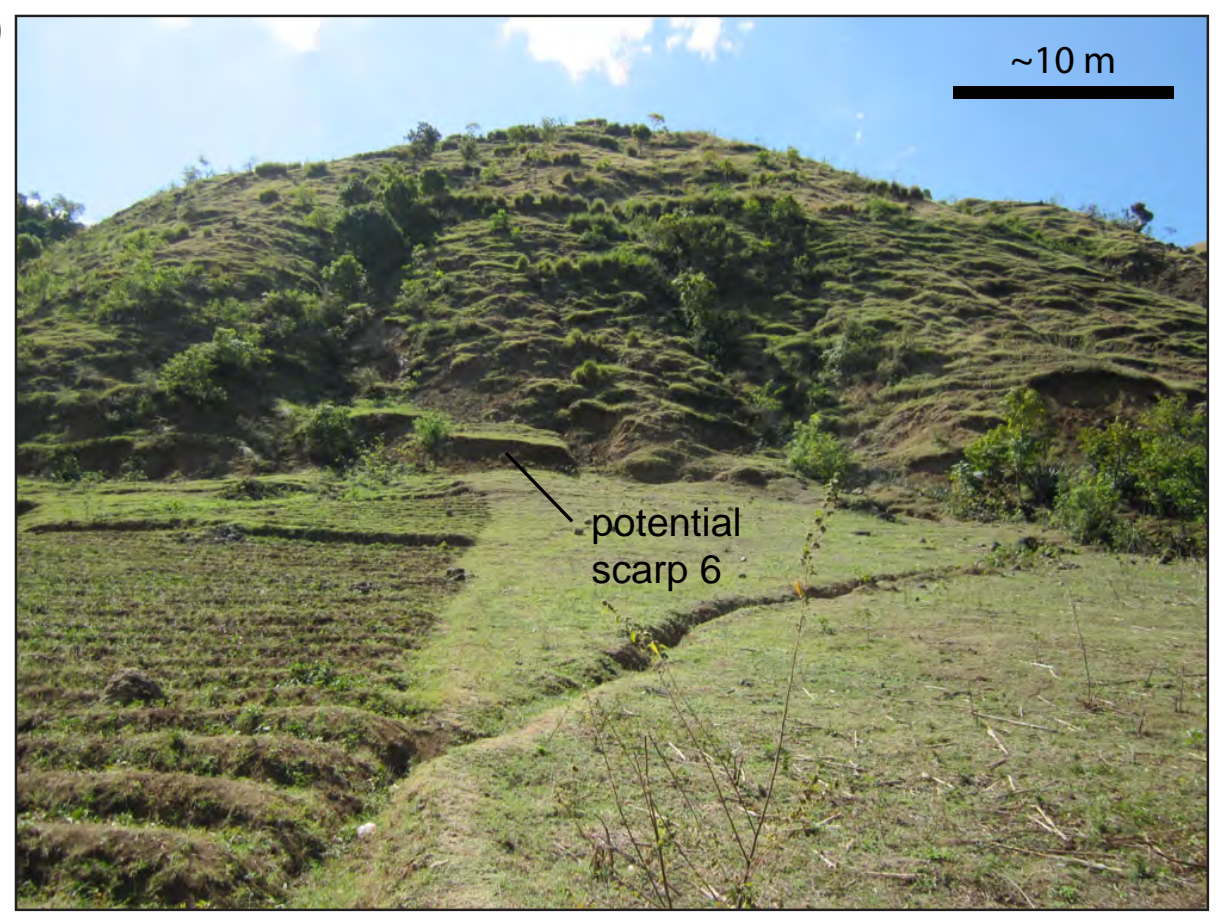

(B)

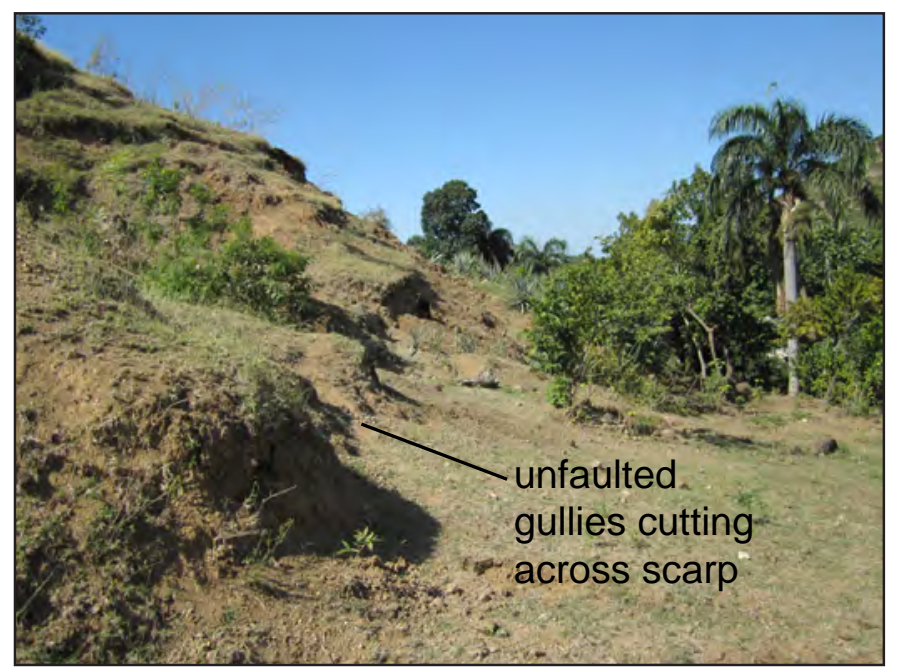

(C)

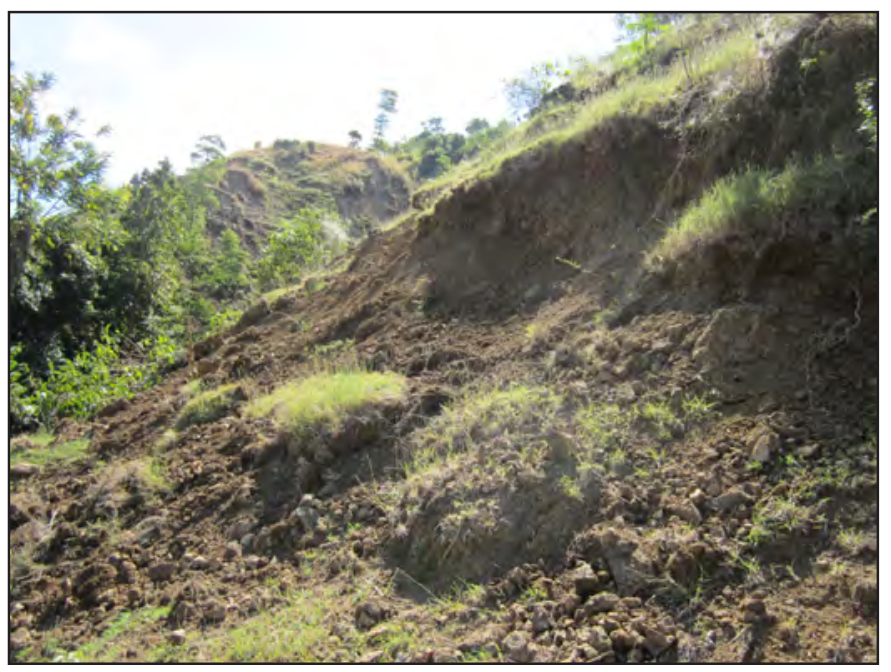

Figure 7. Photographs of potential scarp 6 at the back edge of a fluvial terrace east of Fayette at Site B. (A) View to the south showing scarp and gullies eroded into scarp; figure $5 B$ shows location. (B) View to the west, and (C) to the east, along the scarp shown in (A). 
(A)

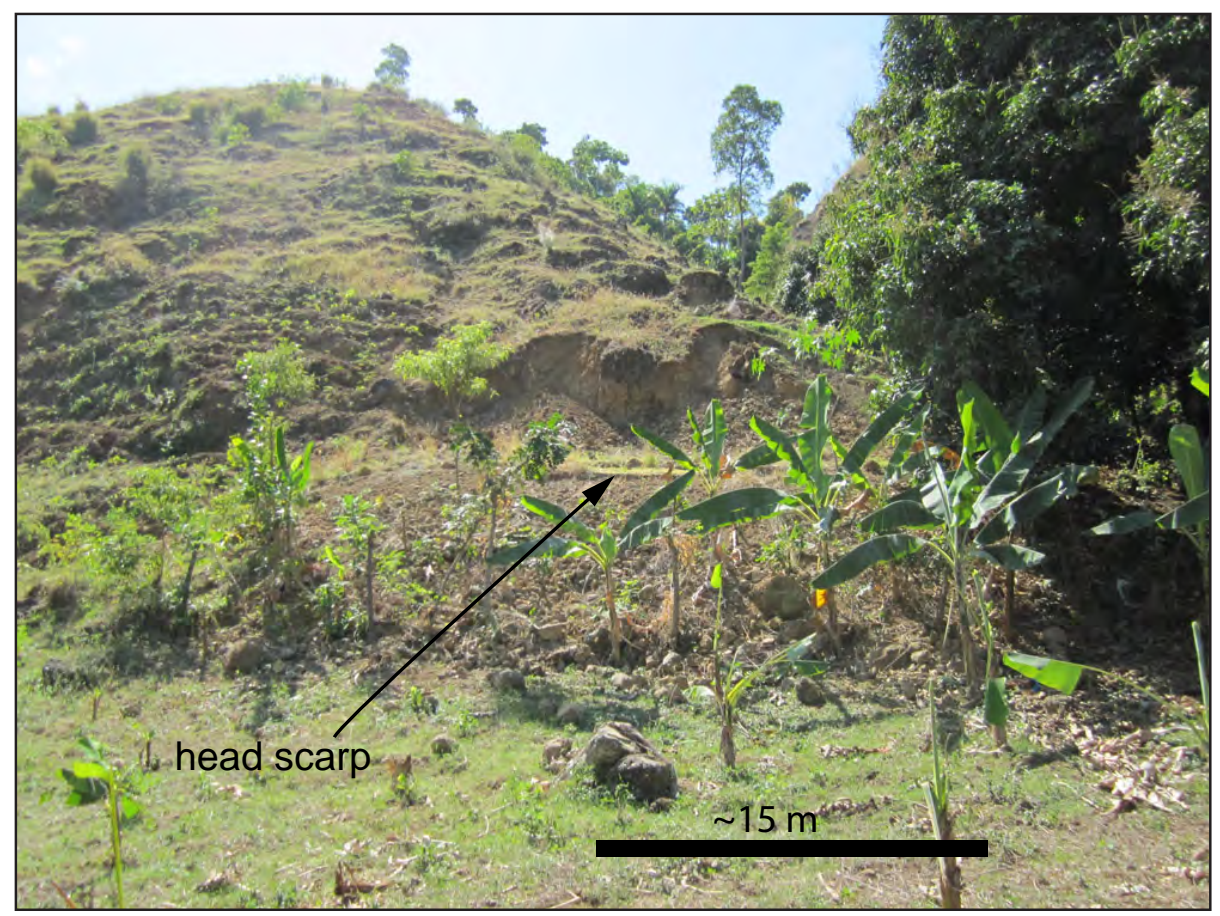

(B)

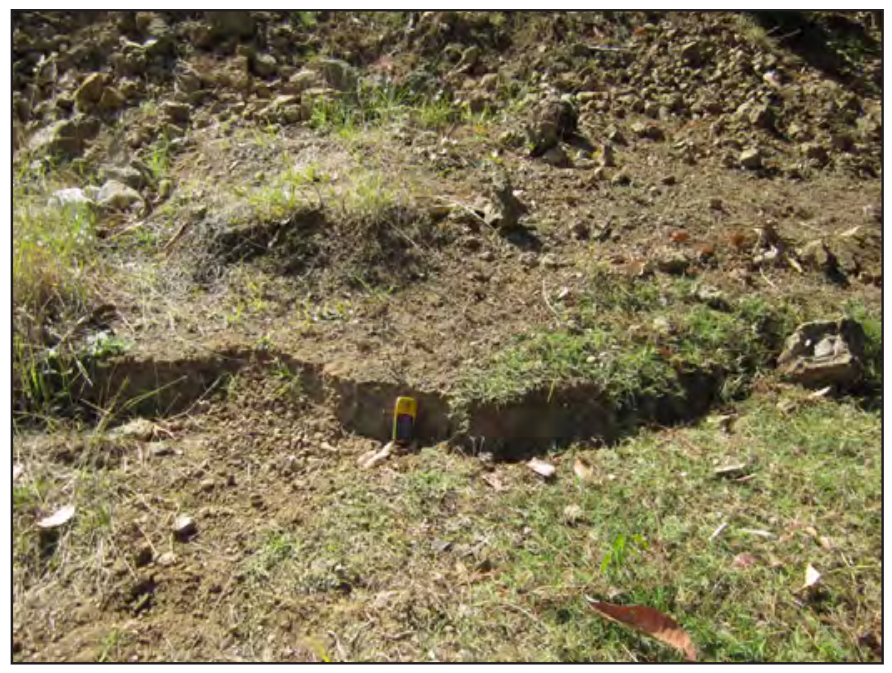

(C)

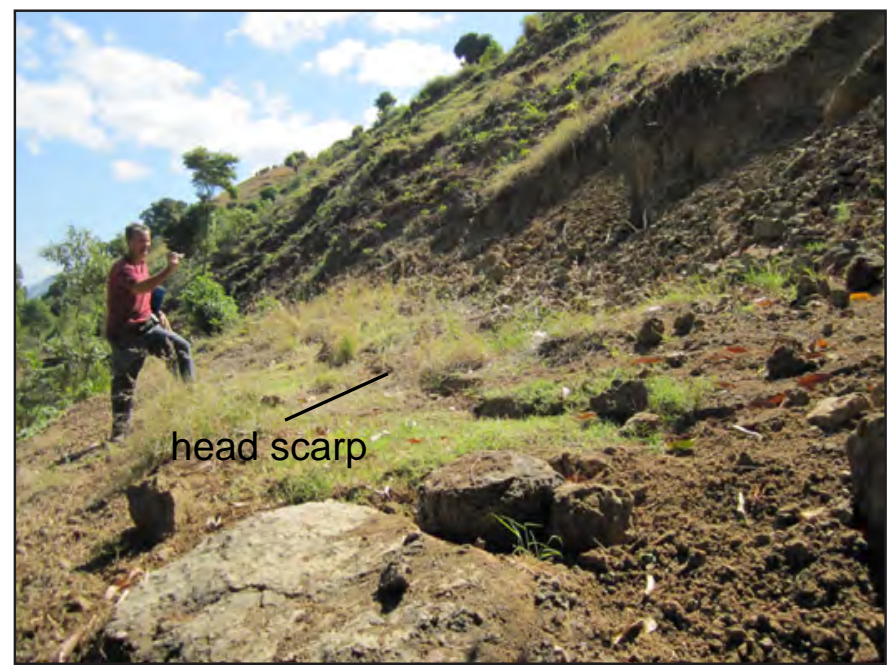

Figure 8. Slump feature along range front at Site B. (A) View to the south of earth slump feature along the fault trace; location is shown in figure 5. (B) Close-up view of the slump head scarp; GPS unit for scale. (C) View to the east along the head scarp; person for scale. 
the fault, we cannot preclude a surface rupture origin for this feature. However, the scarp is not continuous, and similar features were not observed elsewhere along the scarp. Thus, we infer that this feature is more consistent with an earth slump origin. Large blocks of limestone up to $1 \mathrm{~m}$ in diameter occur $>10 \mathrm{~m}$ from the range front adjacent to the slide feature (fig. 9A). Pervasive rockfall also occurs along the main river valley east and west of Site B (fig. 9B).

\section{Enriquillo fault near Dufort, Site C}

We performed ground reconnaissance with a team of geologists from Geotechnical Extreme Events Reconnaissance (GEER) along a potential fault valley approximately $1 \mathrm{~km}$ southwest of the town of Dufort (Site C, fig. 1, $18^{\circ} 26^{\prime} 49^{\prime \prime} \mathrm{N}, 72^{\circ} 38^{\prime} 37^{\prime \prime} \mathrm{W}$ ). At this location, tectonic geomorphology indicative of active strike-slip deformation includes a large shutter ridge, closed depressions, sag ponds, linear valleys, sidehill benches, and beheaded channels (fig. 10). A photograph looking north at the fault valley is shown on figure 11 . We walked two traverses perpendicular to the trace of the fault across the fault valley in the area shown (black oval) in figure 10. In particular, we examined the break in slope at the northern and southern edges of the fault valley, as well as all sides of the shutter ridge. We refer to the two closed depressions shown on figure 10 as 'closed depression north' (CDN) and 'closed depression south' (CDS) in the following discussion.

CDN is an elongate $\sim 0.5$-km-long valley that contains a dry sag pond that was occupied by a tent camp housing displaced citizens during our visit (figs. 12A and 12B). Tectonic scarps do not occur within the valley or along its margins. Figure 12C shows the base of the shutter ridge that bounds the southern side of the depression. The topographic transition from the valley to the shutter ridge is smooth and unbroken. CDS also contains a dry sag pond and trends roughly parallel to CDN (figs. 10 and 13A). A small, 0.5 -m-high scarp extends along the southern margin of CDS (figs. 13B and 13C). This scarp is characterized by a rounded crest and base and is vegetated with grass. Freshly exposed surfaces do not occur along the base of the scarp and it is not continuous. We infer that this feature is of cultural/ agricultural origin. Multiple randomly oriented ground cracks were observed on the floor of the valley (fig. 14A). The cracks are open $<1 \mathrm{~cm}$ and are not arranged in any particular pattern (such as en echelon steps). The floor of the valley was dry at the time of our visit, but is likely wet during the rainy season. Thus, the cracks are more consistent with shrink-swell processes acting on the clayey valley-fill sediments and may have been accentuated by strong ground shaking. Secondary effects of strong ground shaking observed in closed depression south include a boulder that was displaced $\sim 12 \mathrm{~cm}$ to the east (fig. 14B) and toppled gravestones (fig. 14C).

Prominent tectonic geomorphology in the valley southwest of Dufort suggests Quaternary fault activity; however, active traces of the fault are not well expressed and our reconnaissance did not uncover any evidence for surface rupture within the valley. Directly west of Dufort, along Highway 200, anomalous topography including a linear range front, several elongate ridges, and linear swampy depressions suggest that a trace of the fault may parallel the highway. We did not investigate this area in detail. About $900 \mathrm{~m}$ east of Dufort along the southern edge of the alluvial plain, a subtle north-facing scarp $\left(18^{\circ} 27^{\prime} 13^{\prime \prime} \mathrm{N}, 72^{\circ} 37^{\prime} 25^{\prime \prime} \mathrm{W}\right)$ associated with a swampy closed depression may be the location of the fault and a possible location for future paleoseismic study. On the basis of the lack of topographic evidence for the presence of the fault or progressive deformation of the alluvial plain north of Dufort, our tectonic geomorphic observations suggest that the fault may bend slightly south from the mouth of the Rivière Momance near Fayette and project along the southern edge of the alluvial plain toward the vicinity of Dufort. This interpretation of the fault contrasts with interpretations of the location of the fault based on imagery, which suggested a more eastwest projection from the mouth of the Rivière Momance fault valley to the coast.

\section{Highway 200 between Dufort and Leogâne, Site D}

Ground fractures observed on GeoEye Inc. imagery between Dufort and Leogâne that were initially thought to be surface rupture along Route 200 were assessed with geologists and engineers from the Geo-engineering Extreme Events Reconnaissance (GEER) team (Site D, fig. 1). The cracks were restricted to the roadbed and artificial fills (fig. 15) and did not extend into the adjacent lowlands. The cracking may reflect localized settlement and cracking/movement of the road fill and underlying subgrade resulting from deformation of soft, organic, and saturated alluvial soils (GEER, 2010), and are not related to surface rupture. Detailed descriptions and photographs of these features, as well as descriptions of the engineering properties of the surrounding soils, are contained in GEER (2010).

\section{Coast west of Leogâne, uplifted coral reef, Site $\mathbf{E}$}

We briefly visited an uplifted coral reef along the coast west of Leogâne (Site E, figs. 1 and 16A, $18^{\circ} 31$ '31"N, 72³9'4"W) with the GEER team. Observations consistent with local uplift include many coral heads exposed above the water level, a drained intertidal lagoon adjacent to the reef, and a broad, subaerially exposed reef platform supporting subtidal sea grass (fig. 16 and 17A). 
(A)

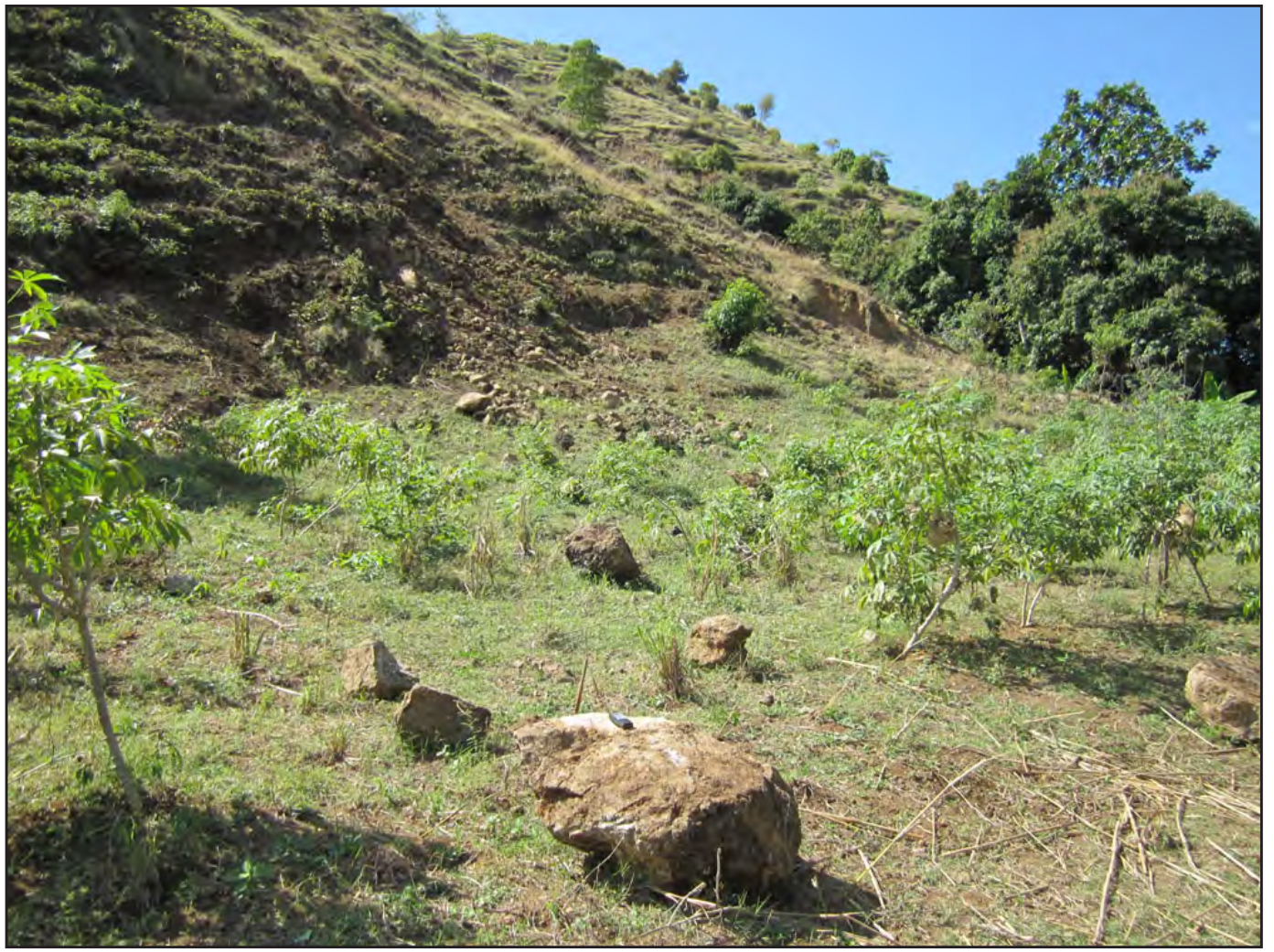

(B)

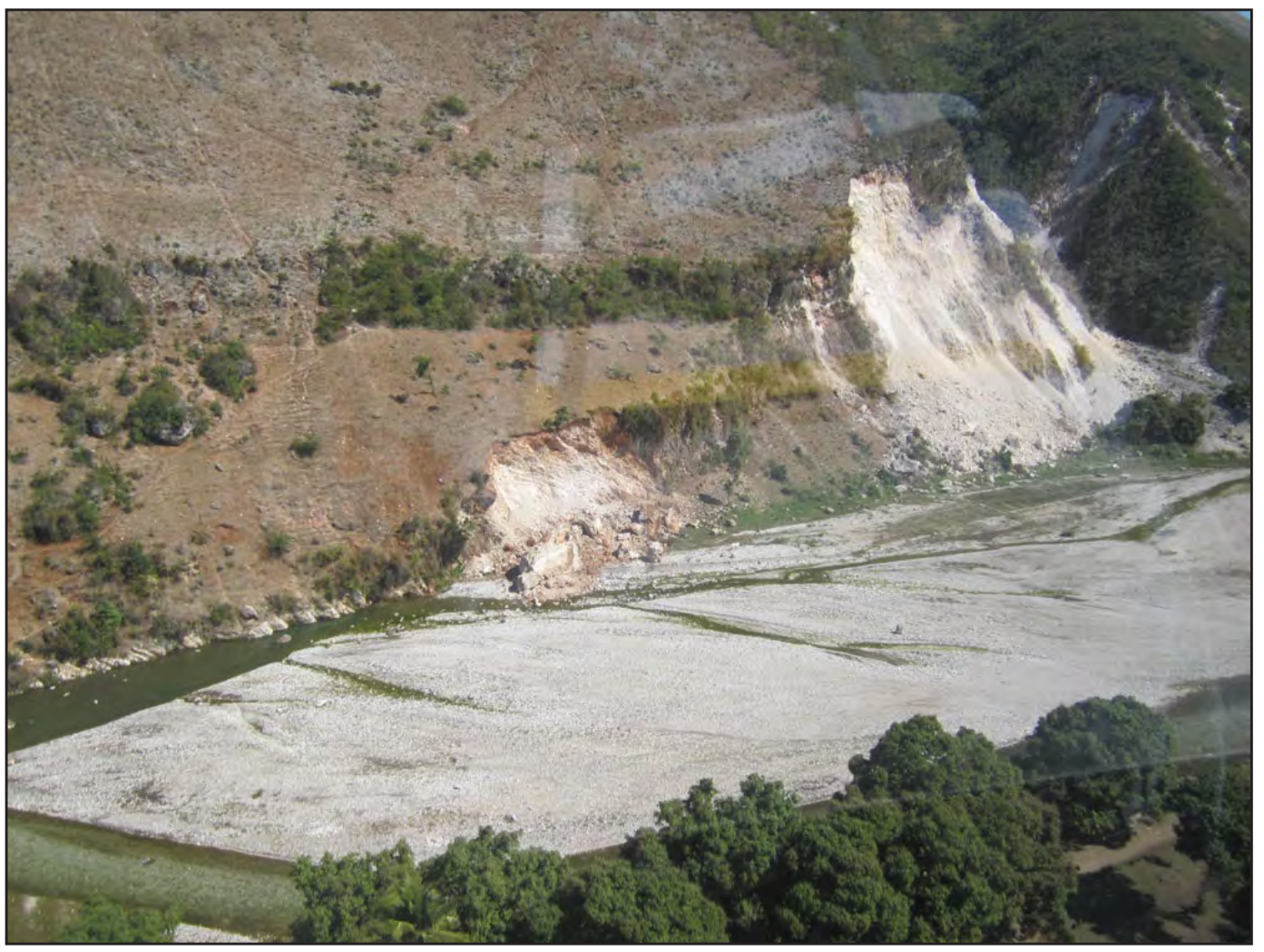

Figure 9. (A) Rockfall along the back edge of the terrace at Site B. Rock in foreground is $\sim 1 \mathrm{~m}$ in diameter. (B) Rockfall along the main river channel near Site B. Scar in center of photo is approximately $10 \mathrm{~m}$ high. 


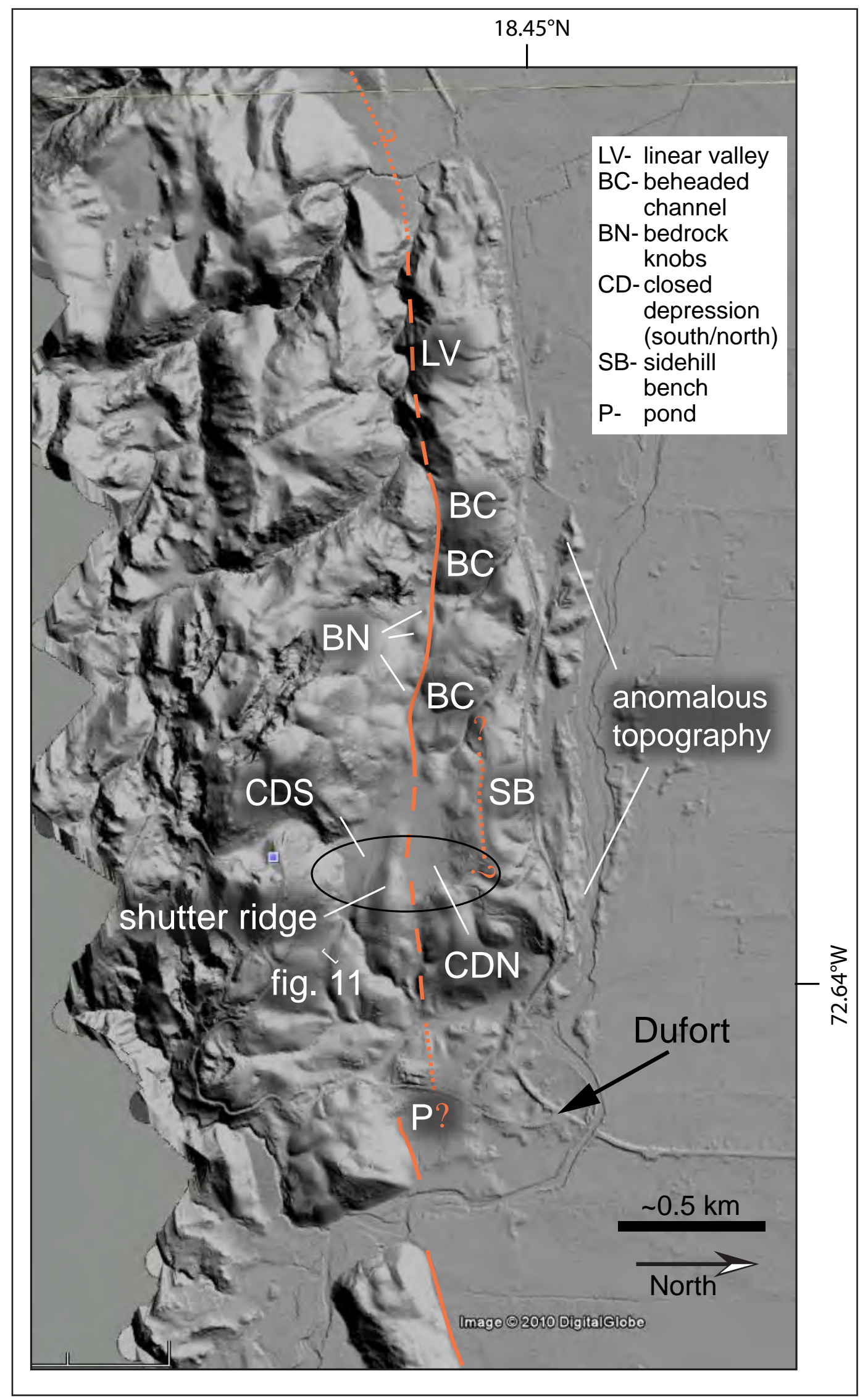




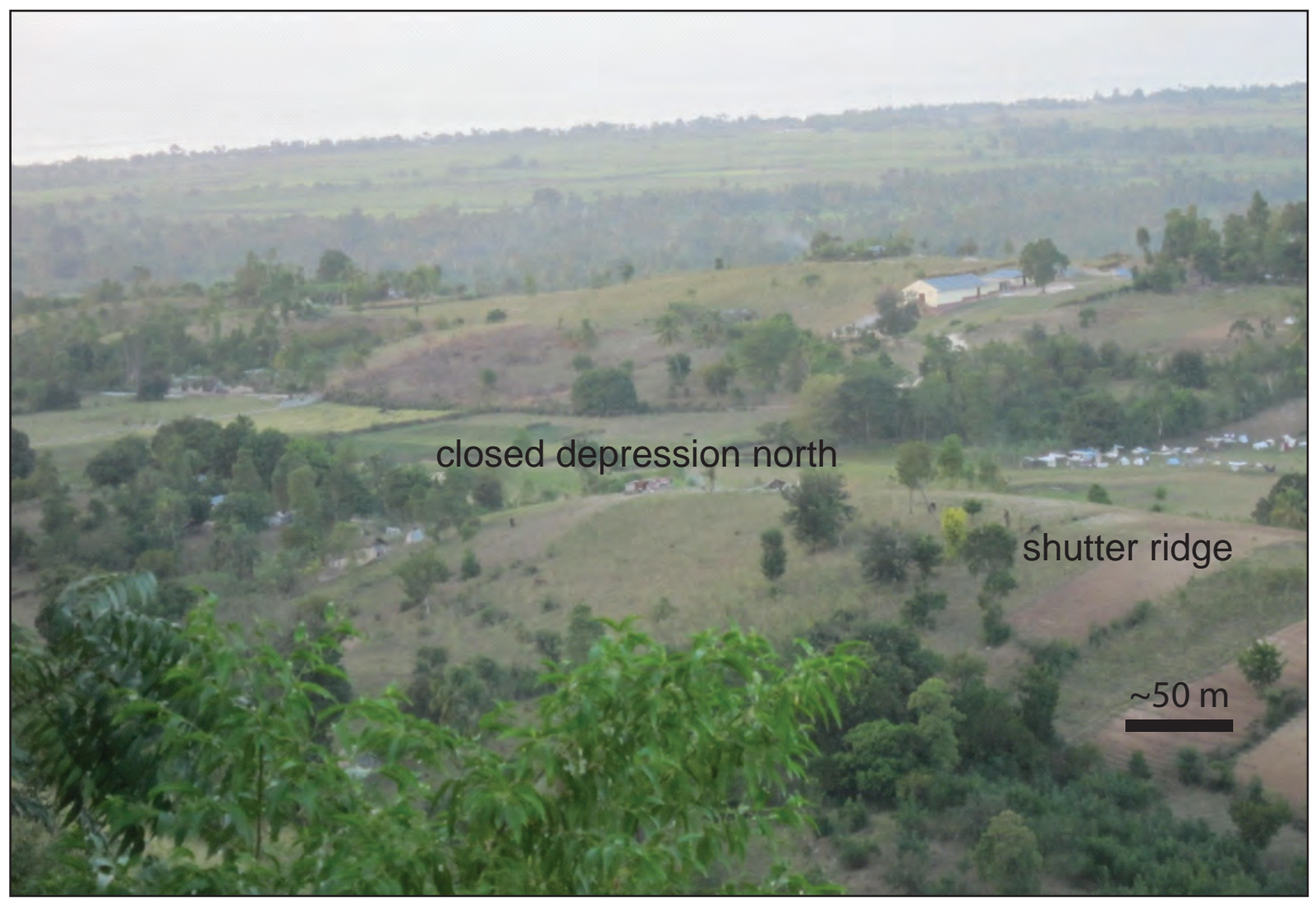

Figure 11. Photograph of the fault valley southwest of Dufort. View is to the northwest, looking across shutter ridge and closed depression north (CDN). Photo location is shown on figure 10.

Figure 10 (previous page). LiDAR image of Site C, a fault valley southwest of Dufort. Tectonic geomorphic features are annotated; fault is shown in orange. LiDAR courtesy of Rochester Institute of Technology (RIT), processed by C. Crosby, San Diego Supercomputer Center.

A distinct black stain line along a concrete wall associated with French colonial Fort Leogâne at the back edge of the beach was interpreted to represent the former high tide line (fig. 17B). We used this line as an elevation datum to assist in calculations of the amount of uplift. At 4:43 p.m. local time, we measured the elevation difference from this line to (1) the water level at the time of our visit (78 cm); and (2) the level of the last high tide $(63 \mathrm{~cm})$. We also measured the difference in elevation between the last high tide and the water level at the time of our visit $(17 \mathrm{~cm})$. Additionally, we collected a sample of the coral head. Measurements from the top of the coral head and the top of the sample to the water elevation were $20 \mathrm{~cm}$ and $15 \mathrm{~cm}$, respectively. The estimate of the previous high tide elevation was tenuous because there was only a subtle litter line and minor escarpment to mark its location. Local residents indicated that the subtle litter line was the elevation of the last high tide, however, this elevation should be treated with caution. A more prominent litter line consisting of sea grass exists above the elevation of the last high tide. On the basis of the small tidal range at this location $(0.4-0.6 \mathrm{~m})$, we infer that the more prominent litter line may be related to the tide line at the time of the earthquake. We provided our measurements to Rich Briggs, USGS, to perform preliminary tidal modeling to determine the tide at the time of the event. Briggs calculated a rough estimate of $\sim 50-60 \mathrm{~cm}$ of uplift based on this model. Another description of the reef is contained in GEER (2010). Detailed measurements of the uplifted reef features were performed subsequent to our brief visit (Hayes and others, 2010). Results of the Hayes and others (2010) study are consistent with our reconnaissance result and indicate that $0.64 \pm 0.11 \mathrm{~m}$ of coseismic uplift elevated coral reefs along $55 \mathrm{~km}$ of coastline from Gressier to Port Royal.

We uncovered several industry seismic lines and maps from the 1980s, by crawling into the damaged library of the Bureau des Mines et de l'Energie Haiti (fig. 17C). These data show a northwest-trending fault with a north-side-up sense of motion intersecting the coast south of Leogâne Point. The sense of motion is consistent with the regional pattern of uplift and may indicate sympathetic rupture on this fault. 

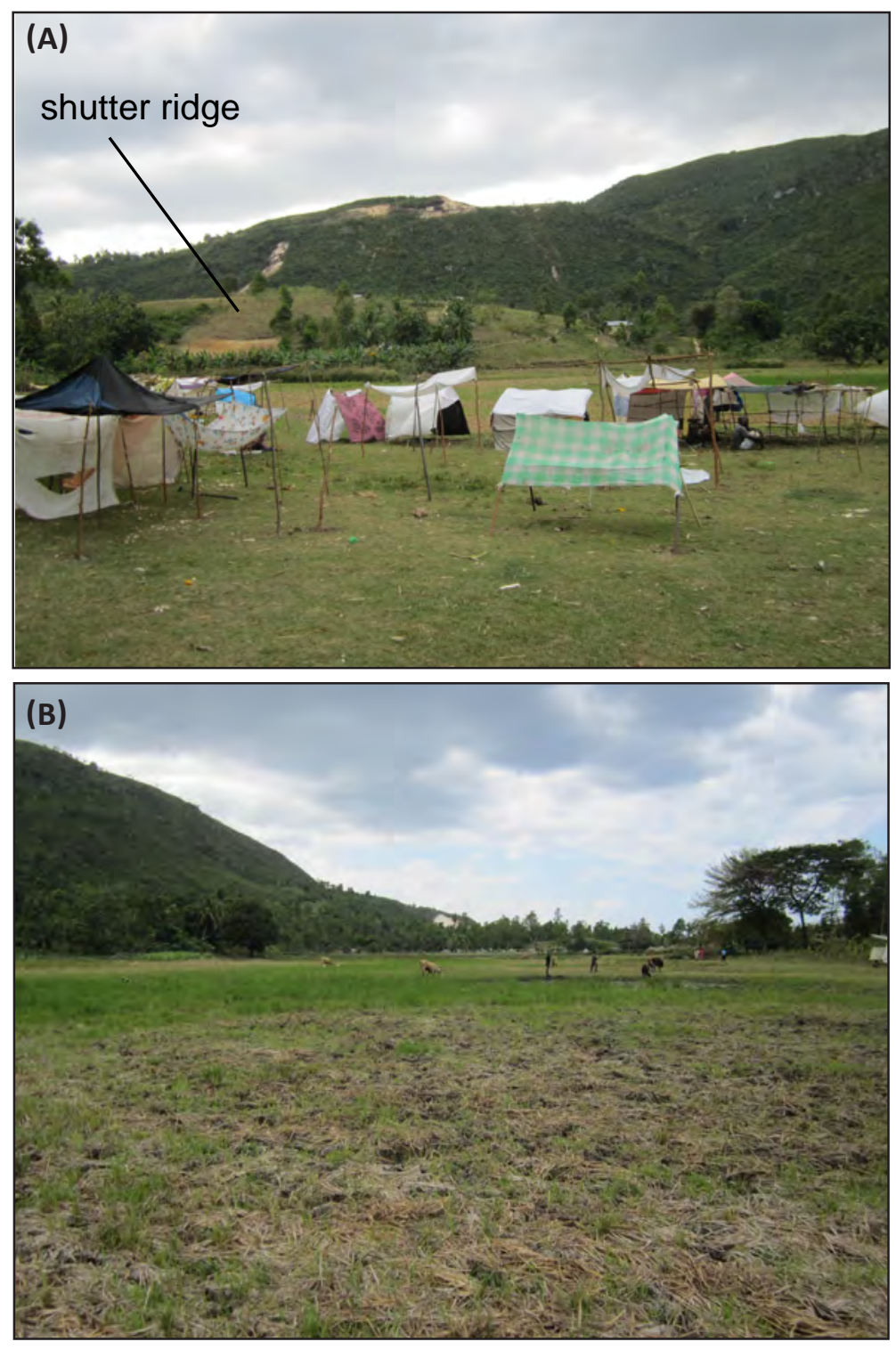

(C)

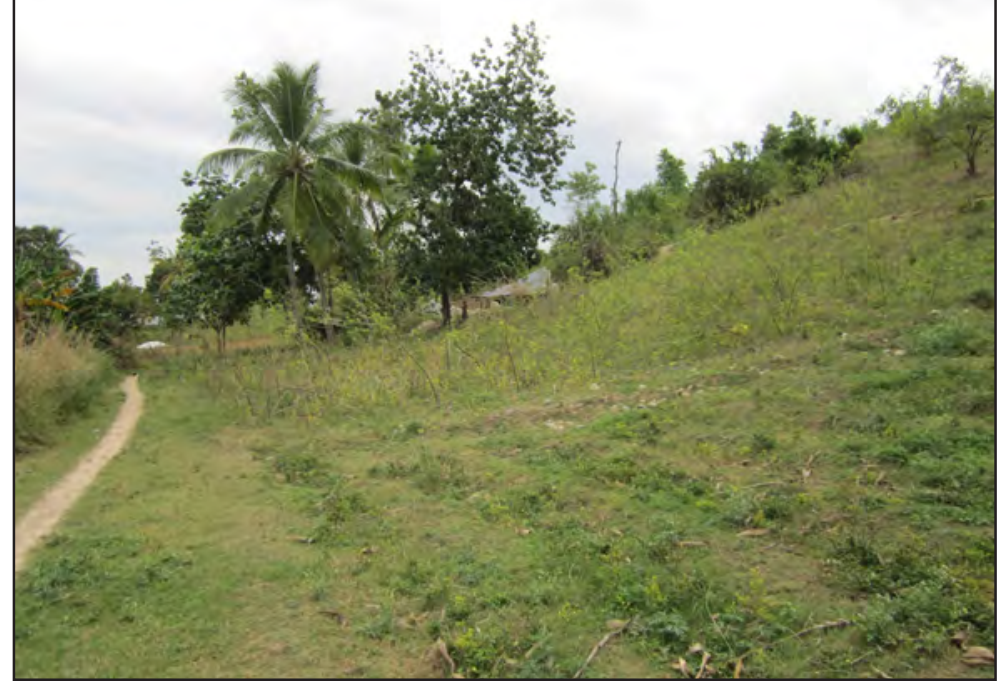

Figure 12. Photographs at Site C, southwest of Dufort, showing closed depression north $(C D N)$. (A) View to the south across the valley showing the shutter ridge that bounds the southern margin of the valley; relief shelters provide scale. (B) View west down the axis of the valley; cows for scale. (C) Looking east at the base of the shutter ridge; footpath for scale. Photos $12 \mathrm{~A}$ and $12 \mathrm{~B}$ taken from the same location $\left(18^{\circ} 21^{\prime} 53^{\prime \prime} \mathrm{N}\right.$, $\left.72^{\circ} 38^{\prime} 39^{\prime \prime} \mathrm{W}\right)$. Photo in $12 \mathrm{C}$ taken from $18^{\circ} 26^{\prime} 48^{\prime \prime} \mathrm{N}, 72^{\circ} 38^{\prime} 42^{\prime \prime} \mathrm{W}$. 


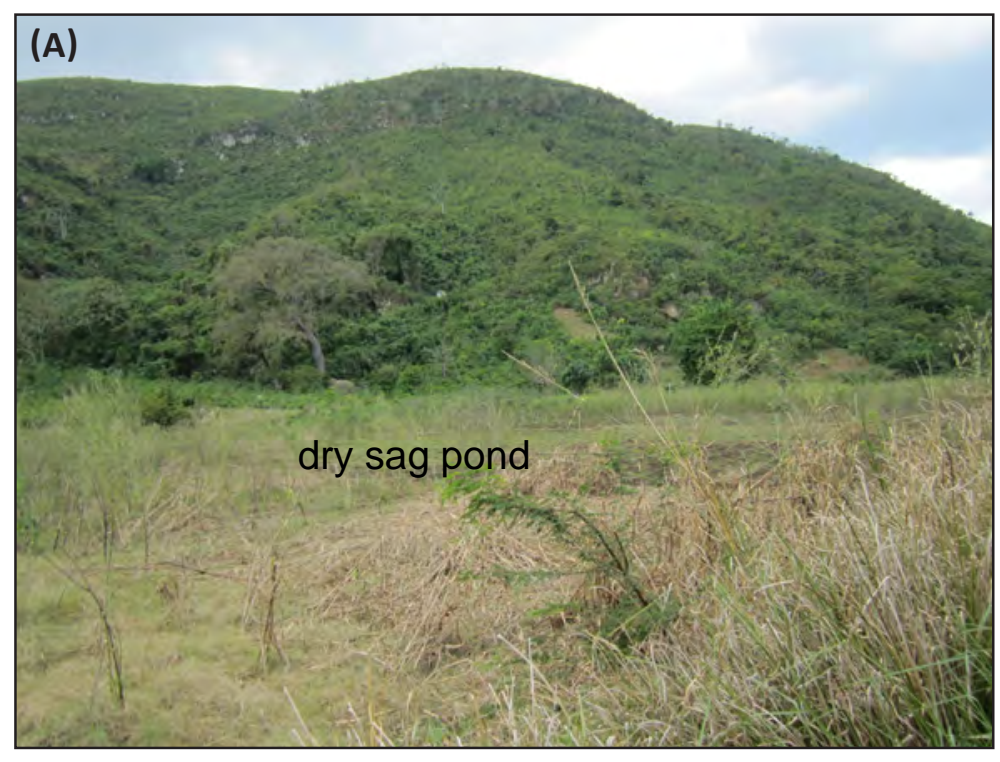

Figure 13. Photographs of Site C, southwest of Dufort, showing closed depression south (CDS). (A) Dry sag pond located at $18^{\circ} 26^{\prime} 42^{\prime \prime} \mathrm{N}$, $72^{\circ} 38^{\prime} 44^{\prime \prime} W$. (B) Cultural scarp on south side of valley; people for scale. (C) Vegetated face of cultural scarp located at $18^{\circ} 26^{\prime} 40^{\prime \prime} \mathrm{N}, 72^{\circ} 38^{\prime} 38^{\prime \prime} \mathrm{W}$; scarp is $\sim 0.5 \mathrm{~m}$ high.
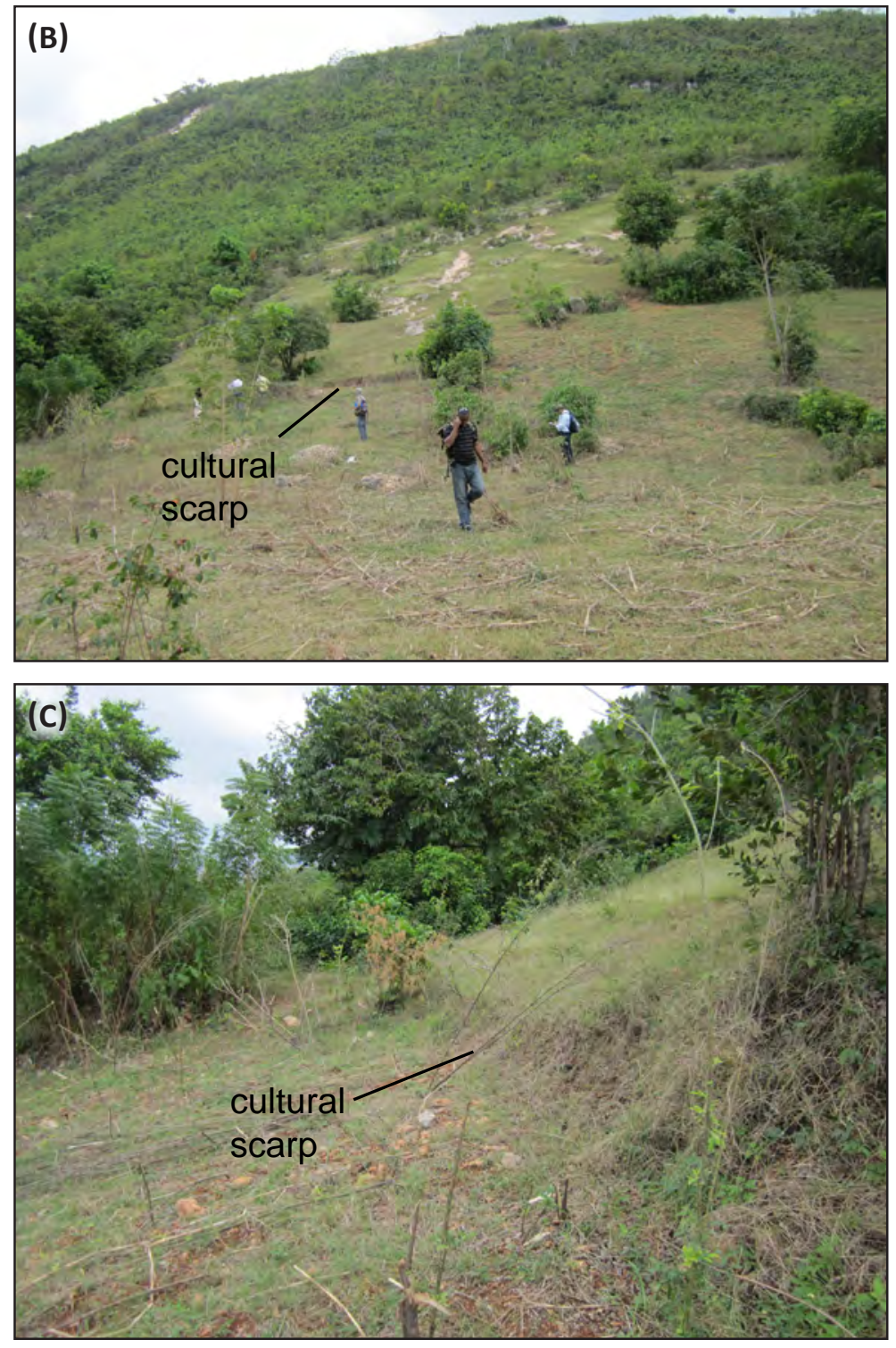
(A)

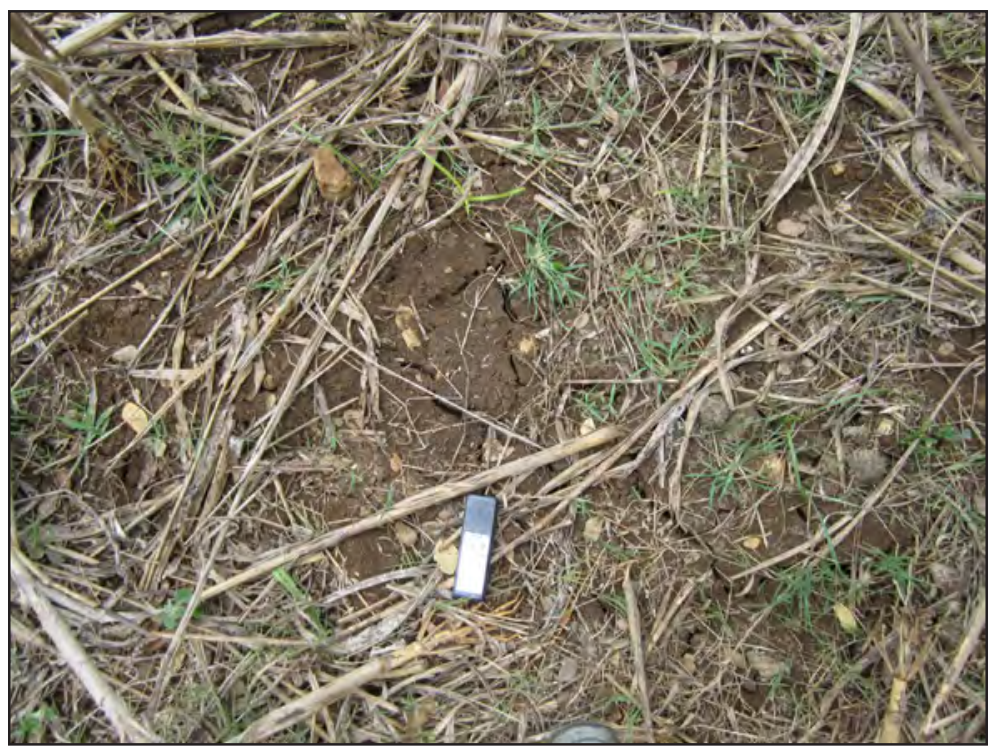

(B)

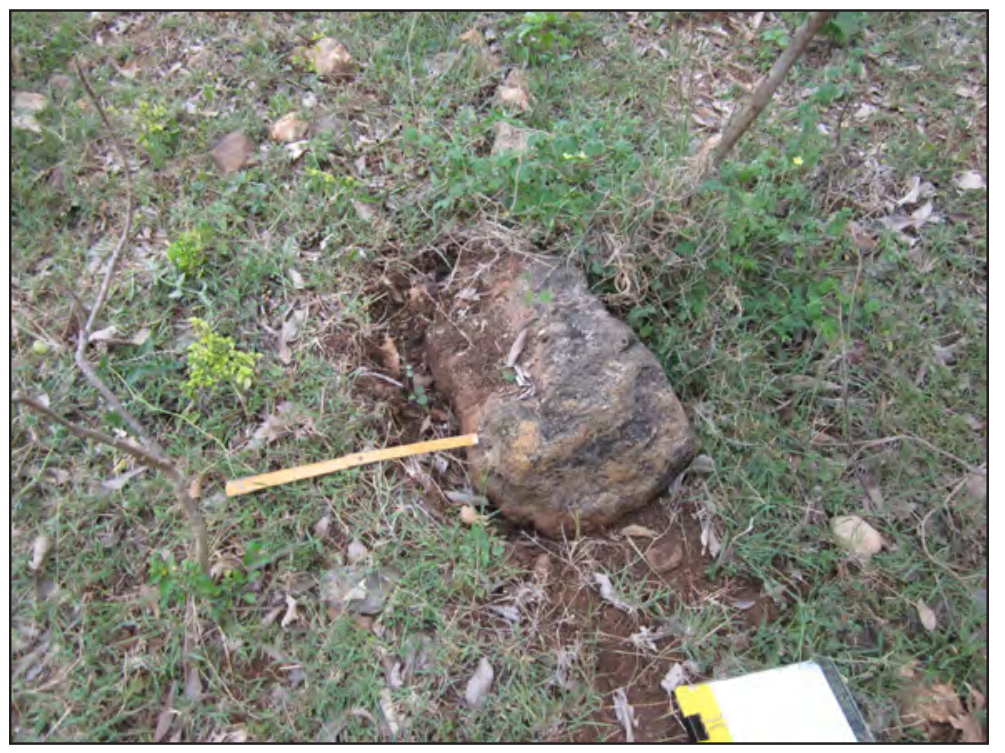

(C)

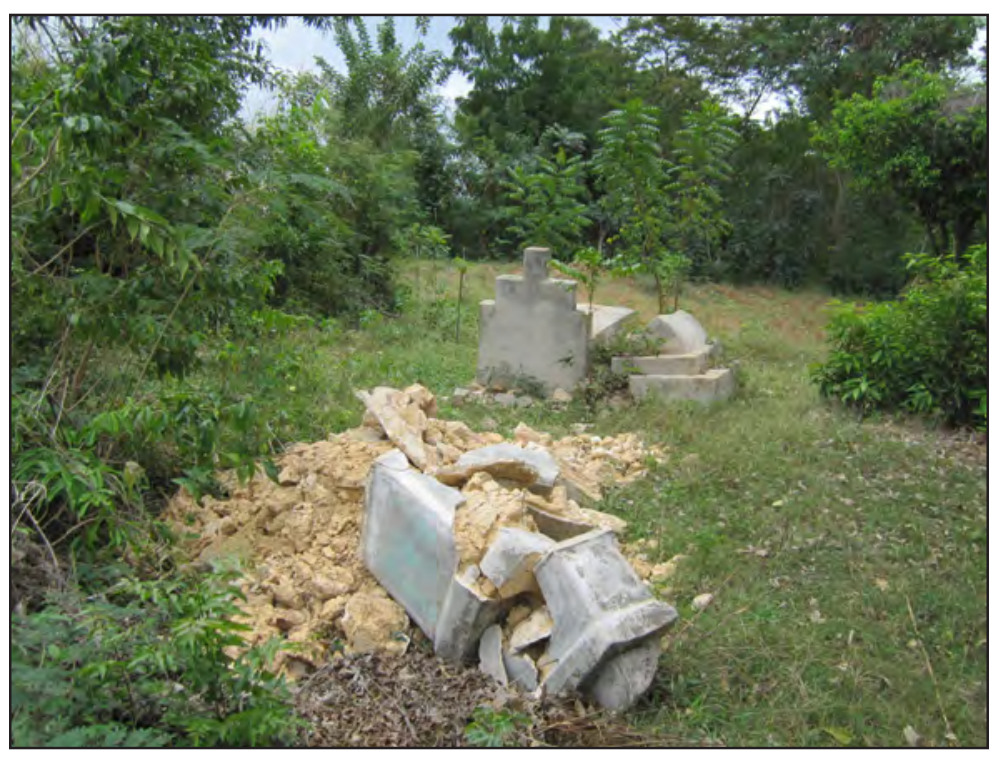

Figure 14. Additional photographs of Site C. (A) Shrink-swell cracks in floor of closed depression south (CDS), located at $18^{\circ} 26^{\prime} 42^{\prime \prime} N, 72^{\circ} 38^{\prime} 42^{\prime \prime} W$. Tape recorder for scale. (B) Displaced boulder (notebook for scale) and $(C)$ toppled gravestones (standing gravestone is $\sim 1 \mathrm{~m}$ high) are evidence of strong ground motions on the southfacing slope of the shutter ridge near $18^{\circ} 26^{\prime} 45^{\prime \prime} \mathrm{N}, 72^{\circ} 38^{\prime} 37^{\prime \prime} \mathrm{W}$. 


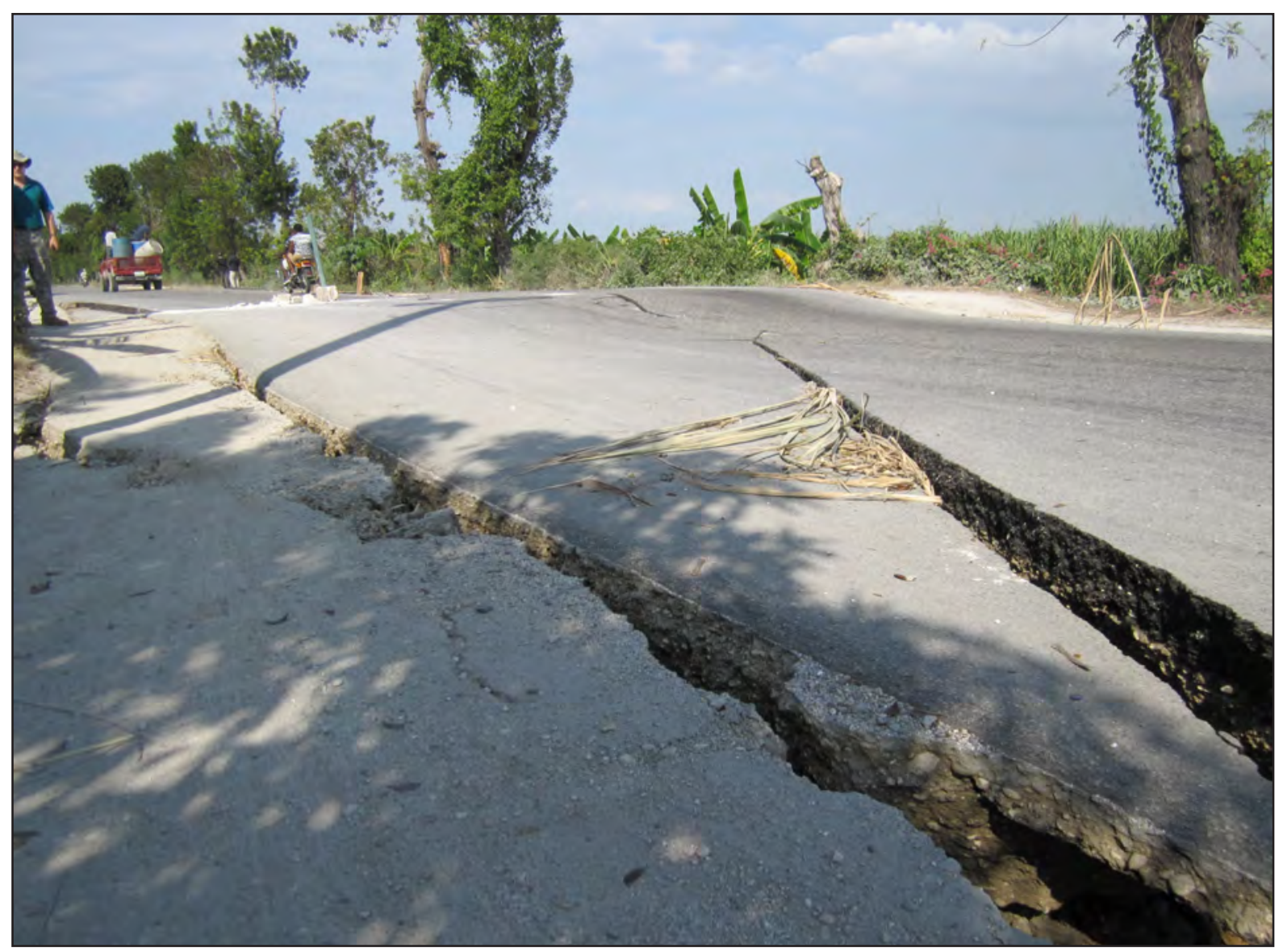

Figure 15. Example of cracks in the pavement along Highway 200 at Site D north of Dufort; people provide scale. Cracking was observed in the road fill prism at nearly every culvert crossing on the highway between Leogâne and Dufort.

\section{River mouth directly east of Fouche, Site F}

A limited amount of time was spent looking at a ground-failure feature at the mouth of the Fauche River delta (Site F, fig. $1,18^{\circ} 25^{\prime} 34$ "N, $72^{\circ} 43^{\prime} 35^{\prime \prime} W$ ). At this location a $\sim 300$-m-wide section of the delta fan and the beach were transported into the ocean (fig. 18A). The delta alluvium is characterized by interbedded lenses of sand, gravel, and rounded $4-10 \mathrm{~cm}$ cobbles in a sand matrix. Many submerged trees were observed in both straight growth position and tilted toward the coast, indicating seaward transport of intact blocks. Along the eastern side of the feature, coast-parallel cracks and grabens occur up to $15 \mathrm{~m}$ inland from the coast and are associated with vented sand and gravel. One prominent graben $15 \mathrm{~m}$ long by $2 \mathrm{~m}$ wide by $1 \mathrm{~m}$ deep extends along the backside of a laterally transported block (fig. 18B). A 1.5-m-high headscarp occurs in the center of the delta fan. About a dozen coast-parallel cracks with several centimeters of coast-side-down displacement occur within a 10-m-wide zone inland of the headscarp. The saturated condition of the alluvium, presence of loose lenses of fine- to medium-grained sand, and liquefaction were determined to be the likely contributing factors to lateral spreading of the delta front. Following our field visit, the GEER team performed more detailed studies including spectral analyses of seismic waves and dynamic cone penetration tests. The data collected are included in GEER (2010).

\section{DISCUSSION AND CONCLUSIONS}

Our reconnaissance of the 2010 Haiti earthquake confirms the lack of primary surface fault rupture along the main Enriquillo fault in the area studied, between the Rivière Momance valley and Port Royal. En echelon, south-directed extensional cracks extending east of Port Royal may represent triggered slip (Prentice and others, 2010). Secondary deformation related to strong ground shaking was widely observed and included debris avalanches, rockfall, road-fill prism settlement, and collapsed buildings. Uplift of coral reef platforms along the Leogâne coast suggests rupture along a subsidiary thrust fault, consistent with the rupture modeling of Hayes and others (2010) and mapped faults on industry seismic lines. Hornbach and others (2010) suggest the 

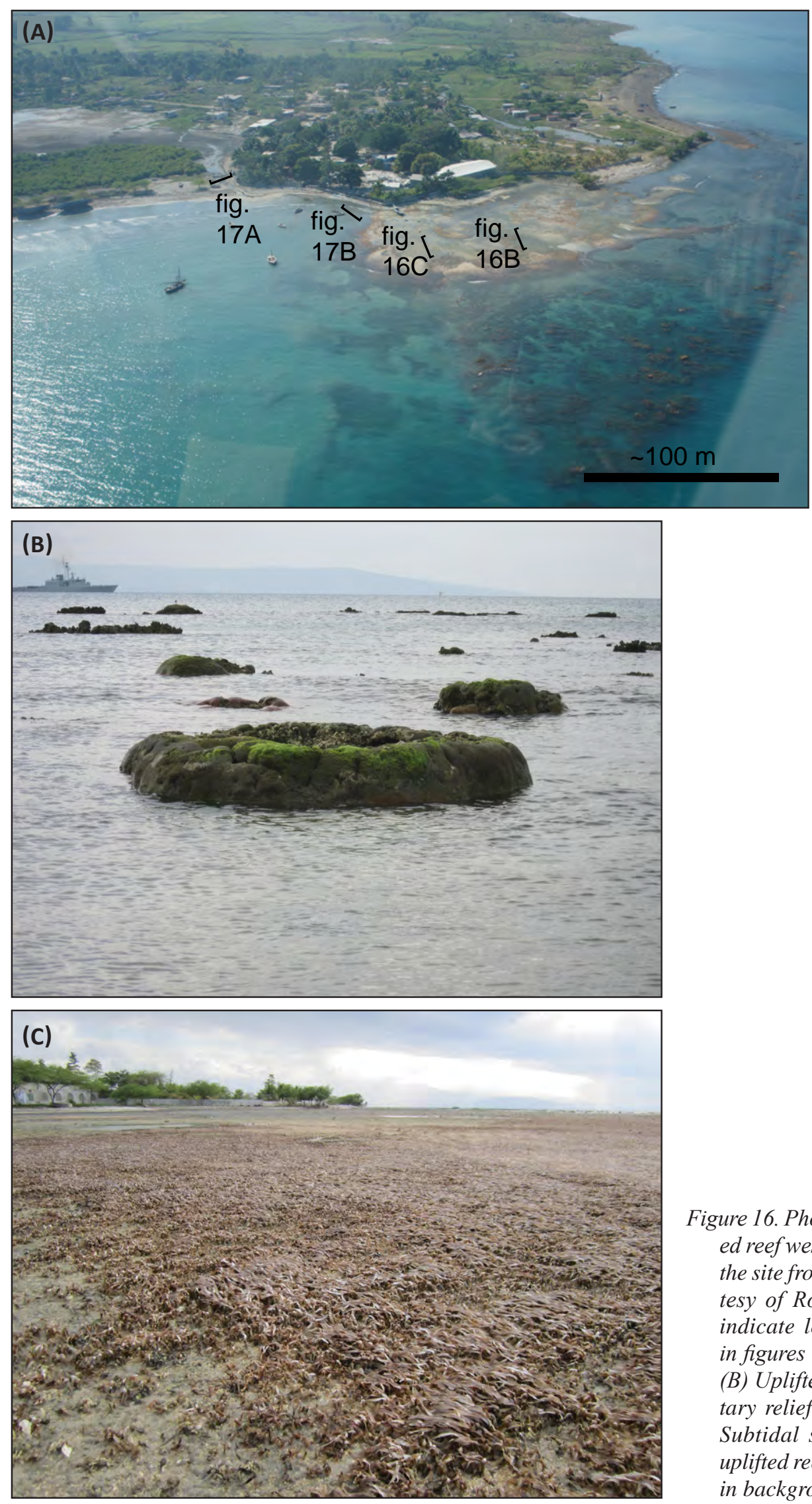

Figure 16. Photographs of Site E, uplifted reef west of Leogâne. (A) View of the site from helicopter (photo courtesy of Rodger Bilham). Brackets indicate locations of photographs in figures 16B, 16C, 17A, and 17B. (B) Uplifted coral heads; U.S. military relief ship provides scale. (C) Subtidal sea grass is exposed on uplifted reef platform. Concrete wall in background is $~ 2 \mathrm{~m}$ high. 


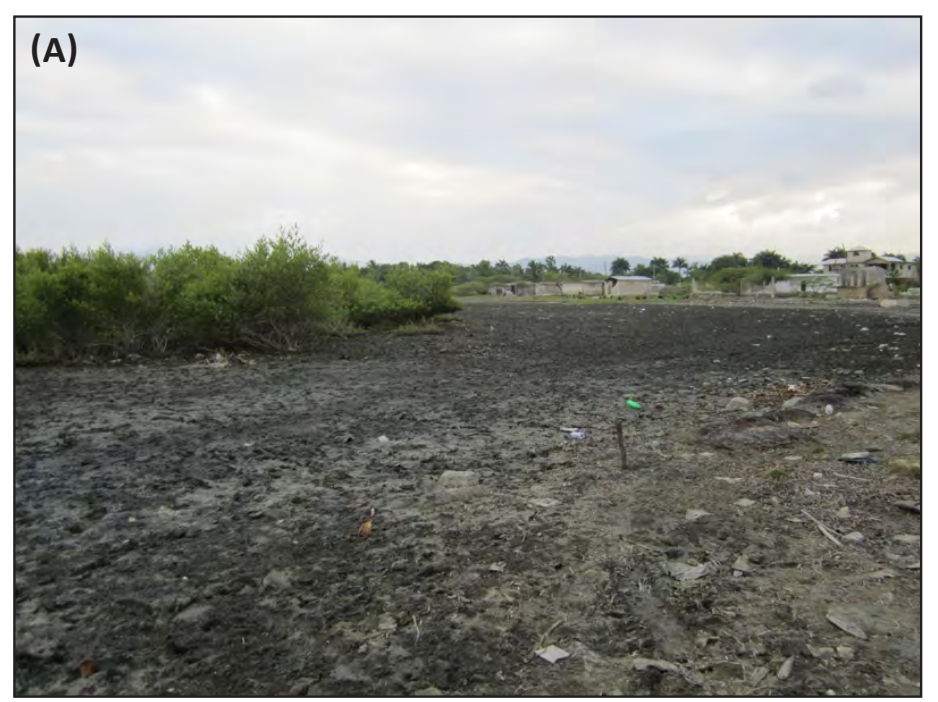

Figure 17. Photographs of Site E, uplifted reef west of Leogâne. (A) Drained tidal marsh adjacent to reef; houses in background for scale. (B) Former high-tide elevation marked by the black stain line on concrete wall. Yellow measuring stick $\sim 30 \mathrm{~cm}$ tall provides scale. (C) Map from the Bureau des Mines et de l'Energie Haiti showing fault with up-on-the-north sense of motion in the vicinity of Leogâne Point.
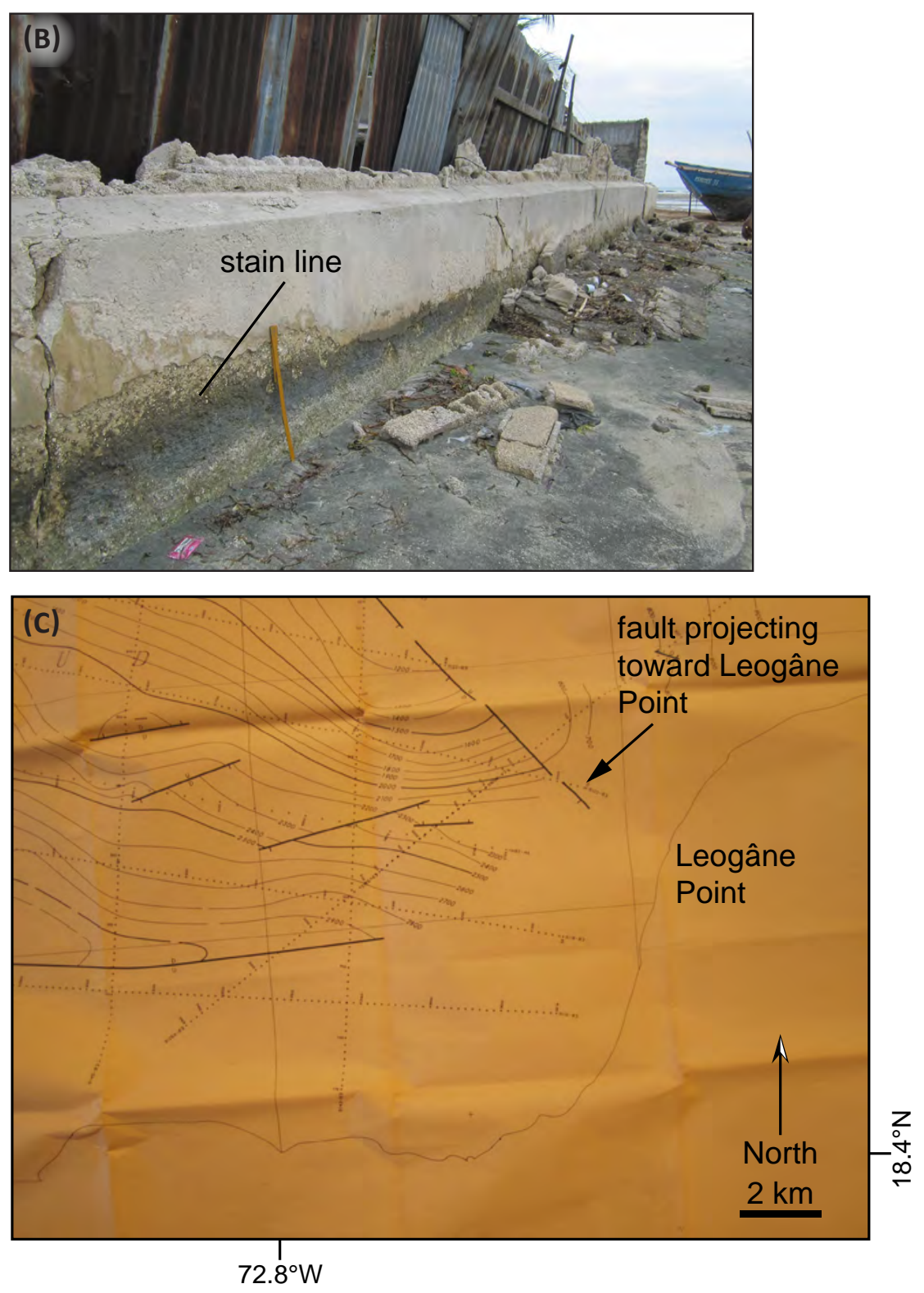
(A)

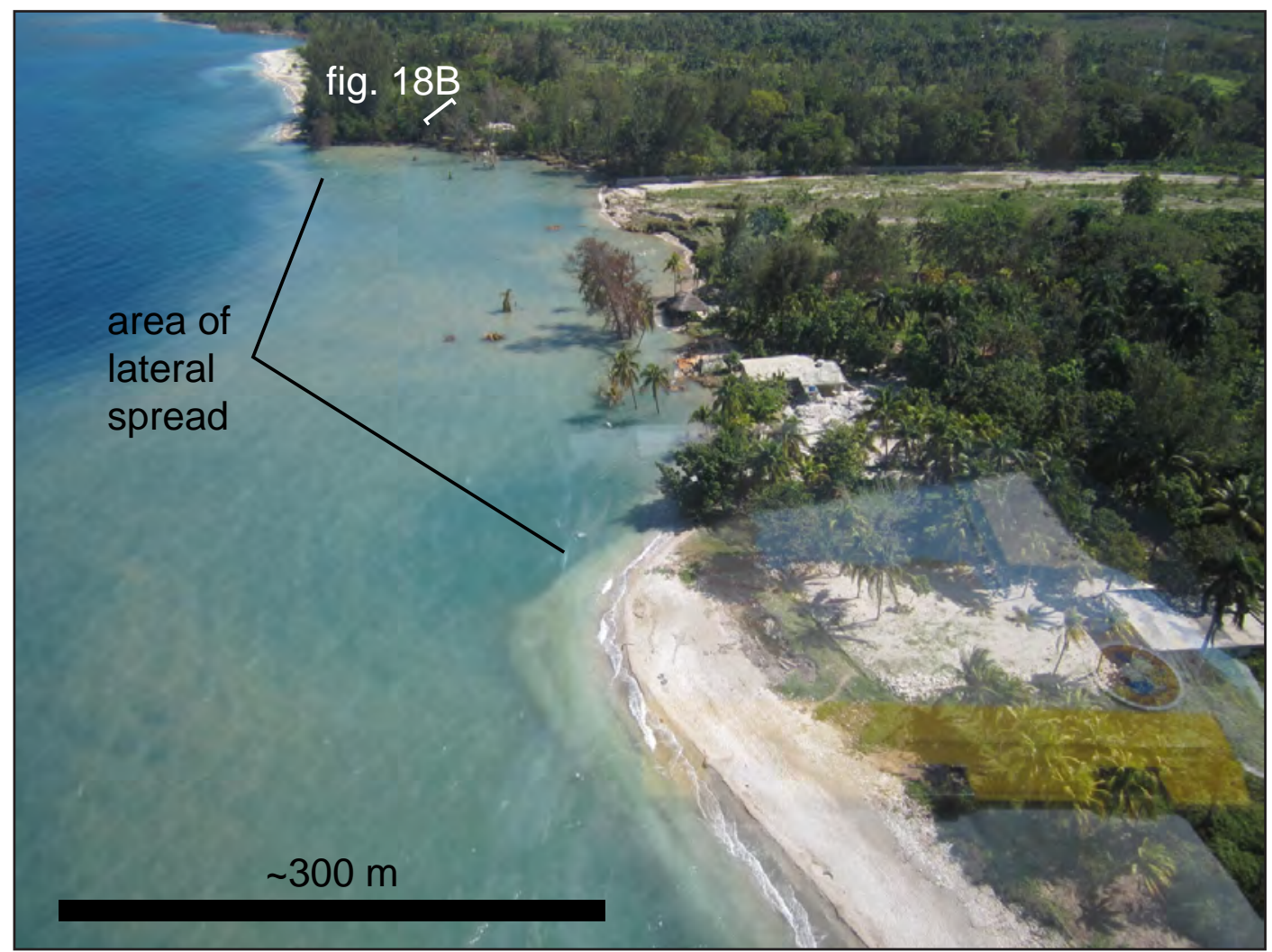

(B)

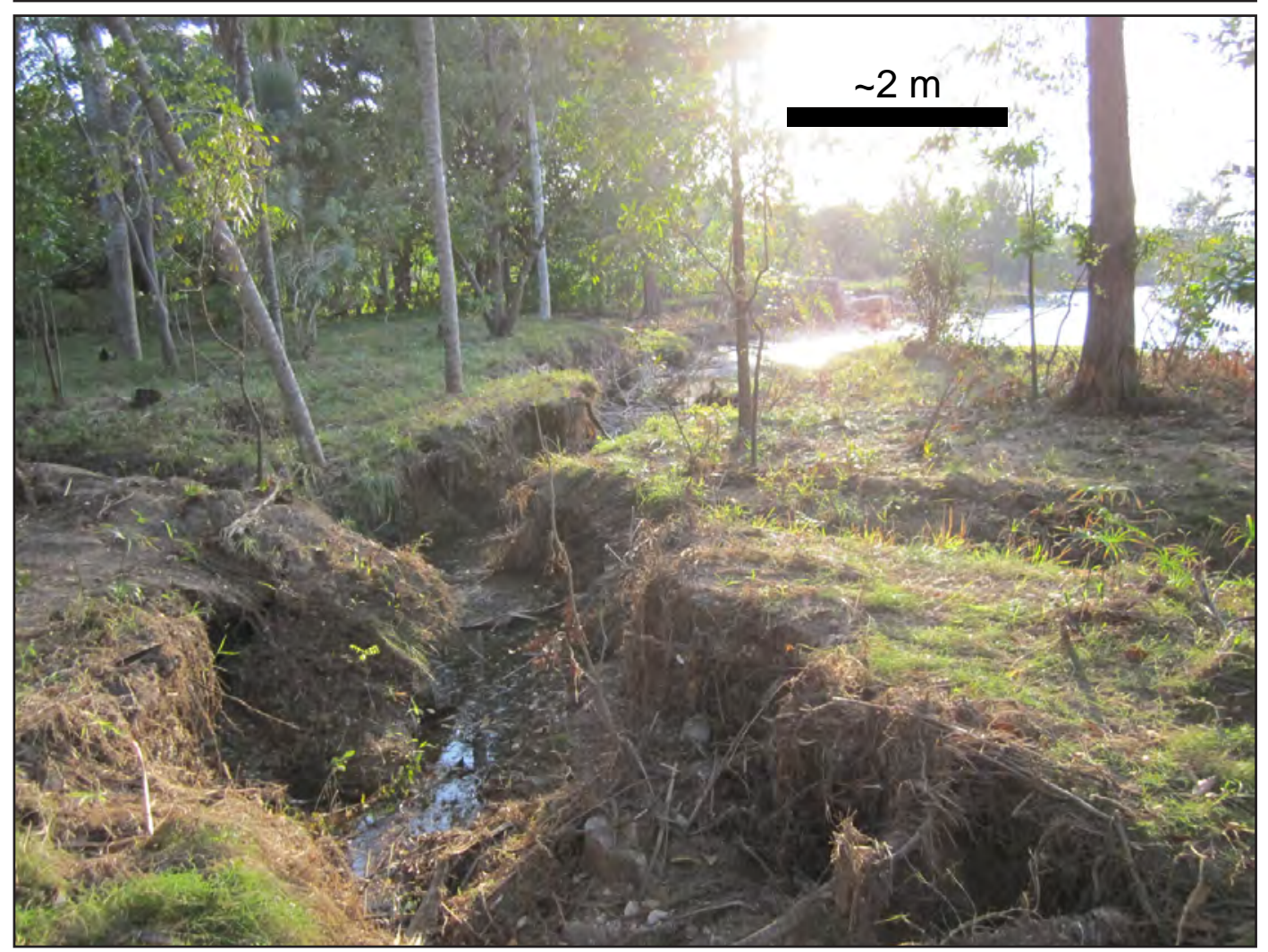

Figure 18. Photographs of Site F near Fouche. (A) Cuspate area labeled is a large lateral spread indicated by missing beach, coast-parallel cracks, and submerged trees. (B) Head scarp cracks up to $2 \mathrm{~m}$ wide and $1 \mathrm{~m}$ deep appear along eastern side of lateral spread. 
possibility of up to $30 \mathrm{~cm}$ of vertical displacement of the seafloor across an offshore strand of the fault northeast of Fouche, but note that the observed offset may not have occurred during the 2010 event.

Probabilities of future earthquake occurrences are largely dependent on the recurrence interval of past earthquakes documented in trenches, and expected future magnitude assessments rely on accurate assessment of potential future earthquake rupture lengths. The 2010 Haiti earthquake was not associated with surface slip along the Enriquillo fault and involved rupture of multiple related faults north of the main trace (Hayes and others, 2010; Prentice and others, 2010). Thus, deformation patterns documented in the Haiti event have direct implications for the assessment of seismic hazards along other strike-slip boundaries characterized by structural complexities, including New Zealand, California, Alaska, and other areas.

The lack of surface rupture along the Enriquillo fault indicates that the history of earthquakes determined by trenching investigations along the main trace of other faults may be incomplete and evidence of some earthquakes may only be preserved nearby, such as in the coastal uplift and subsidence record of coral reefs in Haiti. In other areas, these damaging earthquakes may not leave detectable evidence in the geologic record, as in the 1989 Loma Prieta earthquake near the San Andreas fault in California (Prentice and Schwartz, 1991). Hayes and others (2010) suggest that near-simultaneous slip on strike-slip and thrust structures is a common occurrence and cite several historical examples to that effect. Rupture of multiple faults, as occurred in the 2002 Denali fault earthquake in Alaska (Aagaard and others, 2004), can result in increased rupture length and magnitude. This emphasizes the need to carefully characterize all faults in a system and consider fault-to-fault interactions.

The distribution of relative plate motion and the timing of earthquakes along individual faults in a system has additional implications for seismic hazards assessment. In Haiti, plate motion is distributed between the Enriquillo and Septentrional faults. Although not the focus of this report, evaluation of the spatial and temporal patterns of earthquake recurrence in Haiti including the long historic record and developing paleoseismic records may reveal patterns in the earthquake process. This information may provide clues to unraveling the seismic potential of other distributed plate boundaries, such as the Fairweather-Denali faults in southeastern Alaska where limited historical and paleoseismic data exist.

The recognition of subtle elevation changes and fault interaction patterns has become increasingly more reliable with advancements in Interferometric Synthetic Aperture Radar (InSAR) and GPS technologies. Field efforts to document the extent of deformation can independently verify estimates of deformation determined geodetically and contribute valuable information to estimating rupture lengths. Thus, combining field and remotely sensed observations is the best way to advance the understanding of the earthquake rupture process.

Communication was disabled in Haiti within the earthquake zone; however, constant email and text updates with developing information viewed on cell phones provided detailed descriptions and locations (GPS coordinates) of suspected surface rupture and other secondary deformation, and became an essential component of our field reconnaissance. Although our reconnaissance benefited greatly from advances in remote sensing and information-sharing techniques, interpretation of remotely sensed imagery alone resulted in erroneous observations at several locations. For example, cracks in the road prism along Highway 200, interpreted by some geologists as surface rupture, were confined to the road prism and determined by site-specific investigation to be secondary deformation features related to settlement of the road fill prism.

The availability of GeoEye, Inc. and LiDAR imagery and modern communication technology allowed the international earthquake geology community to participate in the reconnaissance and assist our field efforts. Interpretations of this imagery led us to determine that the location of the main trace of the fault bends slightly south from the mouth of the Rivière Momance to the vicinity of Dufort, as opposed to earlier interpretations of an east-west orientation. Despite insightful geomorphic observations from the high-resolution imagery, small lateral stream offsets observed in the field at Site B and by Prentice and others (2010) were not originally detected on the imagery.

Direct field observations on the location of the fault, absence of surface rupture on the main trace, geologic material properties, the origin of fractures, and measurements of paleodisplacements and coseismic reef uplift have contributed to a better understanding of the source of the Haiti earthquake and its effects. These data are critical to locating sites for paleoseismic slip rate studies, defining fault geometry, and refining slip models based on teleseismic waves and InSAR. Thus, while technological advances have reshaped earthquake reconnaissance methodology, detailed field observation remains invaluable. A combined approach of remote sensing and field observation during future post-earthquake investigations will better characterize large earthquakes and improve assessment of future earthquake potential.

\section{ACKNOWLEDGMENTS}

This reconnaissance study was funded by a RAPID grant from the National Science Foundation (NSF). We are grateful for transportation, lodging, logistics, and supplies provided by Peter Mitchell and Sam Anderson of Newmont Mining Corporation, Dieuseul Anglade 
of the Bureau des Mines et de l'Energie Haiti, Hugo Dominguez of Everton Minerals, Mark Andersen, and the GEER team. A brief meeting and exchange of information with Roger Bilham of the University of Colorado, who had already been in the field for several days upon our arrival, helped focus our efforts. Coordination with the geodesy group headed by Eric Calais is appreciated. U.S. Geological Survey scientists Rich Briggs, Ryan Gold, Carol Prentice, and Tony Crone kept us informed on developments following the earthquake and provided air photos, GoogleEarth and government classified image observations, and GPS coordinates of specific features. Helpful reviews by Rod Combellick and Sam VanLaningham improved the manuscript.

\section{REFERENCES}

Aagaard, B.T., Anderson, Greg, and Hudnut, K.W., 2004, Dynamic rupture modeling of the transition from thrust to strike-slip motion in the 2002 Denali fault earthquake, Alaska: Bulletin of the Seismological Society of America, v. 94, no. 6, part B, p. S190-S201.

Brown, R.D., and Wolf, E.W., 1972, Map showing recently active breaks along the San Andreas Fault between Point Delgada and Bolinas Bay, California: U.S. Geological Survey Miscellaneous Geologic Investigations Map 1-692.

Geotechnical Extreme Events Reconnaissance (GEER), 2010, Geotechnical engineering reconnaissance of the 2010 Haiti earthquake - Report of the National Science Foundation-Sponsored GEER Team, Version 1, GEER Association Report No. GEER-021, February 22, 2010, http://www.geerassociation. org/GEER Post\%20EQ\%20Reports/Haiti 2010/ Cover Haiti10.html.

Hayes, G.P, Briggs, R.W., Sladen, A., Fielding, E.J., Prentice, C.S., Hudnut, K.W, Mann, Paul, Taylor, F.W., Crone, A.J., Gold, R., Ito, T., and Simons, M., 2010, Complex rupture during the 12 January 2010 Haiti earthquake: Nature Geoscience, v. 3, p. 800-805, DOI:10.1038/ngeo977.

Hornbach, M.J., Braudy, Nicole, Briggs, R.W., Cormier, M.-H., Davis, M.B., Diebold, J.B., Dieudonne, Nicole, Douilly, Roby, Frohlich, Cliff, Gulick, S.P.S., Johnson, H.E. III, Mann, Paul, McHugh, Cecilia, Ryan-Mishkin, Katherine, Prentice, C.S., Seeber, Leonardo, Sorlien, C.C., Steckler, M.S., Symithe, S.J., Taylor, F.W., and Templeton, John, 2010, High tsunami frequency as a result of combined strike-slip faulting and coastal landslides: Nature Geoscience, v. 3, p. 783-788, DOI:10.1038/NGEO975.

Koehler, R.D., Baldwin, J.N, Prentice, C.S, and Pearce, J.P., 2005, Holocene geologic characterization of the northern San Andreas fault, Gualala, California, National Earthquake Hazards Reduction Program Final Technical Report, NEHRP External Grant Award Number 03HQGR0045, 48 p., http://earthquake. usgs.gov/research/external/reports/03HQGR0045. pdf.

Manaker, D.M., Calais, Eric, Freed, A.M., Ali, S.T., Przybylski, P., Mattioli, G.S., Jansma, P.E., Prepetit, C., and de Chabalier, J.B., 2008, Interseismic plate coupling and strain partitioning in the northeastern Caribbean: Geophysical Journal International, v. 174, p. 889-903.

Mann, Paul, Taylor, F.W., Edwards, R. Lawrence, and $\mathrm{Ku}, \mathrm{T} . \mathrm{L} ., 1995$, Actively evolving microplate formation by oblique collision and sideways motion along strike-slip faults - An example from the northeastern Caribbean plate margin: Tectonophysics, v. 246, p. 1-69.

National Earthquake Information Center (NEIC), 2010, Finite fault model link, http://earthquake.usgs. gov/earthquakes/eqinthenews/2010/us2010rja6/ finite fault.php

Prentice, C.S., 1989, Earthquake geology of the northern San Andreas fault near Point Arena, California: Pasadena, California, California Institute of Technology, Ph.D. dissertation, $252 \mathrm{p}$.

Prentice, C.S., and Schwartz, D.P., 1991, Re-evaluation of 1906 surface faulting, geomorphic expression, and seismic hazard along the San Andreas fault in the southern Santa Cruz Mountains: Bulletin of the Seismological Society of America, v. 81, p. 1,424-1,479.

Prentice, C.S., Mann, Paul, Crone, A.J., Gold, R.D., Hudnut, K.W., Briggs, R.W., Koehler, R.D., and Jean, P., 2010, Seismic hazard of the Enriquillo-Plantain Garden fault in Haiti inferred from palaeoseismology: Nature Geoscience, v. 3, p. 789-793, DOI:10.1038/ NGEO991

Wallace, R.E., 1990, ed., The San Andreas Fault System, California: U.S. Geological Survey Professional Paper 1515, 283 p. 